\title{
A review of model-based scenario analysis of poverty for informing
} sustainability \section{Qi Liu ${ }^{1,2, a}$, Zhaoxia Guo ${ }^{1,3}$, Lei Gao ${ }^{4}$, Yucheng Dong ${ }^{1,3}$, Enayat A. Moallemi ${ }^{5}$,} Sibel Eker ${ }^{2,6}$, Jing Yang ${ }^{1}$, Xiaofeng Li $^{1^{*}}$, Michael Obersteiner ${ }^{2,7}$, Brett A. Bryan ${ }^{5}$

${ }^{1}$ Business School, Sichuan University, Chengdu 610065, P.R. China.

${ }^{2}$ International Institute for Applied Systems Analysis, Laxenburg, 2361, Austria.

${ }^{3}$ Soft Science Institute, Sichuan University, Chengdu, 610065, P.R. China.

${ }^{4}$ CSIRO, Waite Campus, Adelaide, South Australia 5064, Australia.

${ }^{5}$ Centre for Integrative Ecology, School of Life and Environmental Sciences, Deakin University, Melbourne, Australia.

${ }^{6}$ Nijmegen School of Management, Radboud University, Netherlands.

${ }^{7}$ The Environmental Change Institute, University of Oxford, the UK.

${ }^{a}$ First author: liuqi_67@stu.scu.edu.cn

* Corresponding author.

\section{Abstract}

Ending poverty in all its forms everywhere is the first goal being targeted by the United Nations 2030 Agenda for Sustainable Development. Poverty eradication is a long-term process that faces the challenges of many uncertainties and complex interactions with other Sustainable Development Goals (SDGs). In order to better understand poverty and contribute to addressing poverty in a sustainable manner, this paper aims to conduct a systematic review of model-based analysis for poverty scenario in the context of SDGs. We first review 144 studies from the perspectives of bibliometric information (i.e., publication types, research topics for poverty, research objects, research scales and geographic locations) and models information for poverty scenario analysis (i.e., model types, purposes, states, temporal and spatial range, sectors considered, poverty and other SDGs indicators). Second, we discuss the pros and cons of different types of models and identify seven representative models. We also discuss the synergies and trade-offs between poverty and other SDGs. Finally, we identify four potential research gaps in model-based poverty scenario analysis and provide suggestions for future research. The review shows that poverty scenario analysis was carried out mainly from a single perspective, such as economic, ecological, and agricultural. Few studies used effective models to analyze poverty under an integrated interactions analysis of multiple sectors. Comprehensive multi-sector models are needed for global and regional poverty scenario analysis over the medium- or long-term to enhance the ability of analyzing the combined effects, synergies, and trade-offs between poverty and a variety of other SDGs.

Keywords: Scenario modeling; Poverty analysis; Sustainable development; Survey

This manuscript is a preprint. The manuscript's status is currently 'submitted' for editorial assessment and a peer-review process. It has yet to be accepted for publication. Subsequent versions of this manuscript may have slightly different content. If accepted, the final version of this manuscript will be available via the 'Peer-reviewed Publication DOI' link. Please feel free to contact the corresponding author; we welcome feedback. 
The United Nations 2030 Agenda for Sustainable Development commonly known as the Sustainable Development Goals (SDGs) is committed to eradicating poverty, protecting the planet, and ensuring peace and prosperity for humanity through concerted actions (Cf, 2015). These SDGs are interdependent and interconnected, and together state the shared aspirations for a more sustainable future. The first goal (SDG 1) of the 17 SDGs, ending poverty in all its forms everywhere, is strongly associated with the well-being of every individual (United Nations, 2019). Although the proportion of people living in extreme poverty (less than \$1.9 a day based on 2011 Purchasing Power Parities (United Nations, 2019)) has fallen from 36\% in 1990 to $10 \%$ in 2015 globally, there are still more than 700 million people living in extreme poverty (United Nations, 2019) where their essential living needs (e.g., water, sanitation, health services, education) cannot be guaranteed. Poverty is still one of the most intractable social problems and the most important livelihood problems faced by humanity (United Nations, 2020).

To better understand poverty and evaluate progress towards SDG 1, researchers have conducted both qualitative and quantitative analyses aiming to identify poverty causes (B. W. Wang et al., 2019), measure the progress towards a set target (VyasDoorgapersad, 2018), understand linkages between poverty and other relevant factors (Suich et al., 2015), and formulate or evaluate the effects of poverty reduction policies (Alwang et al., 2019). However, poverty analysis, as in every other human-natural system analysis (Moallemi et al., 2020), is fraught with challenges of uncertainty (i.e., achieving SDG 1 is a long-term process that is vulnerable to external surprises and shocks) and complexity (interconnections between poverty and other economic, social, and environmental SDGs).

Model-based scenario analysis has been used to tackle these challenges in research on poverty. Regarded as a powerful analytical method to support sustainable development research (Swart et al., 2004), model-based quantitative scenario analysis aims to project possible future trends or consequences under the premise that a phenomenon could occur in the future with a certain likelihood, allowing policymakers to explore alternative futures and to take into account their consequences for decisionmaking (Kosow and Gaßner, 2008). Different from traditional forecasting methods, it emphasizes uncertainty instead of forecasting and works on the premise that there are a variety of possible trends in the future, hence diverse results will be obtained. Scenario analysis uses various sources of information and knowledge (e.g., experience and knowledge of experts, uncertain future trends, and human behaviors) to generate a series of internally consistent future scenarios, which involves highly uncertain longterm driving factors (e.g., demographics, climate change, and technological development) and includes trends or non-linear interactions that may differ significantly from past experiences.

Despite growing interest in model-based scenario analysis in dealing with 
poverty (Allen et al., 2021; Laborde et al., 2021), the depth and breadth of this area and opportunities for further studies have not been scoped so far. Here, we aim to fill this gap by conducting a systematic review of model-based poverty scenario analysis, mapping: (1) the topics addressed; (2) cataloging the quantitative models that have been developed; (3) the indicators used to measure poverty; as well as identifying representative models and research gaps in model-based quantitative poverty scenario analysis. Based on this systematic review we synthesize the field of scenario analysis for assessing poverty and chart a new research agenda for better integrating and mainstreaming this critically important aspect of sustainability into modelling studies.

\section{Methods}

We conducted a systematic review according to the Preferred Reporting Items for Systematic Reviews and Meta-Analyses (PRISMA) protocol (Moher et al., 2009) in three steps (Figure 1).

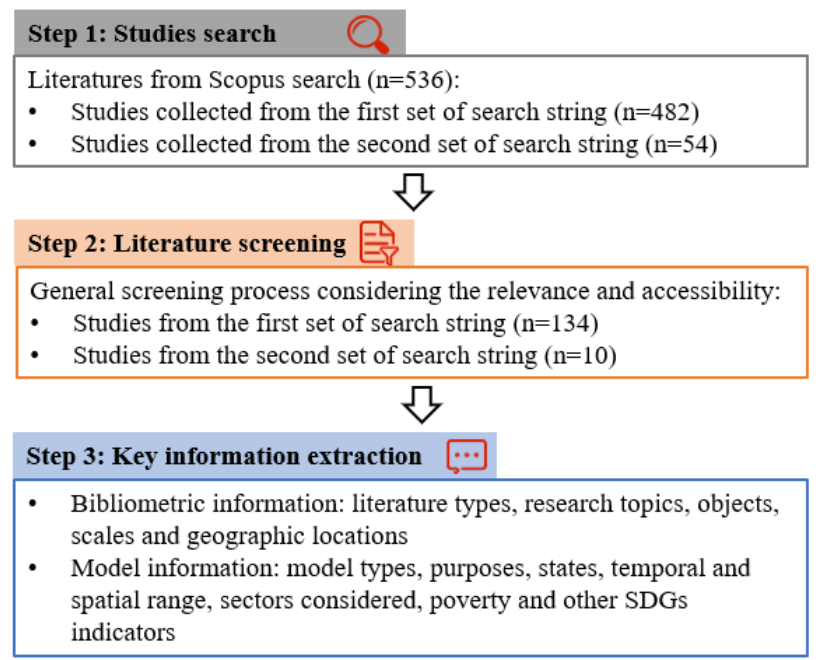

Figure 1. An overview of the steps used for the literature review.

\subsection{Studies search}

The Scopus database is adopted for the literature search because of its broad coverage in related research of poverty, SDGs, system dynamics, and scenario analysis, and internet-accessible full-text resources available in related journals (Mio et al., 2020). The literature search uses specific keywords and their combinations as indexes to search for related literature through titles, abstracts and keywords. The keywords are divided into two groups. The keywords in the first group contain poverty, sustainable development goal 1, and SDG 1 while the second group consists of scenario modeling, scenario analysis, and commonly used scenario analysis model types derived from previous modelling reviews (Allen et al., 2016, 2017), namely system dynamics, computable general equilibrium, integrated assessment model, input-output model, econometric model, and multi-agent model. We set the search time span from January 2015 (the year when SDGs were adopted) to May 2021. We searched for all articles and 
reviews in English and published in journals from the Scopus database. Based on the information above, we found 482 papers by the following search string.

- TITLE-ABS-KEY ("poverty” OR “sustainable development goal 1" OR "SDG 1") AND TITLE-ABS-KEY ("scenario analysis" OR "scenario modeling" OR (scenario AND model) OR (scenario AND modeling) OR "system dynamics" OR CGE OR “computable general equilibrium" OR IAM OR "integrated assessment model" OR "input-output model" OR "econometric model" OR "multi-agent model"); SOURCE TYPE: (Journal).

As some comprehensive models that analyze the SDGs contain poverty modules but were not found by the keywords and search fields above, we used the following search string which returned an additional 54 papers:

- TITLE-ABS-KEY ("sustainable development goals" OR SDGs) AND TITLEABS-KEY ("scenario modeling" OR "scenario model" OR "scenario analysis"); SOURCE TYPE: (Journal).

\subsection{Literature screening}

Literature screening was then undertaken to process the collected 536 papers based on their relevance and accessibility. From the 482 papers obtained from the first search string, we selected 152 papers by browsing the title, abstract, and keywords and excluding irrelevant papers. Excluded papers include art-, psychology-, or medicinerelated papers that were incorrectly captured; papers that only focused on energy poverty, fuel poverty, or food poverty and had no connections with SDG 1; papers that had little connection with poverty (e.g., "poverty" only appear in abstracts as future research). Moreover, we further excluded 18 papers because their full texts could not be accessed online, or the scenario analysis method or model presented was not used or could not be used for poverty analysis. From the 54 papers obtained from the second search string, 10 papers were selected by excluding duplicate and inaccessible papers and papers that did not mention poverty or SDG 1 in the full text. As a result, a total of 144 papers were retained for detailed review.

\subsection{Key information extraction}

By carefully reading each paper, the key information of each paper is recorded from bibliometric and model information and as shown in Table 1. From the perspective of bibliometric information, the research object in a paper represents the population or community studied in each paper. Research scales involve global, regional, national, and local, which cover almost all countries, multiple countries or economies, one country, and a part (e.g., one or more states, cities) of a country, respectively.

147 Table 1. Key information recorded.

\begin{tabular}{lll}
\hline Key information & Meta-indicator & Description \\
\hline
\end{tabular}




\begin{tabular}{|c|c|c|}
\hline \multirow{5}{*}{$\begin{array}{l}\text { Bibliometric } \\
\text { information }\end{array}$} & Publication types & Research articles, review articles. \\
\hline & Research topics & $\begin{array}{c}\text { Socio-economy, agriculture, eco-environment, } \\
\text { other, combinations. }\end{array}$ \\
\hline & Research objects & $\begin{array}{l}\text { Whole population, rural population, children, } \\
\text { women, farmers, workers, etc. }\end{array}$ \\
\hline & Research scales & Global, regional, national, local. \\
\hline & Geographic locations & Differentiated by country. \\
\hline \multirow{7}{*}{$\begin{array}{l}\text { Model } \\
\text { information }\end{array}$} & Model types & $\begin{array}{c}\text { CGE models, econometric models, SD models, } \\
\text { microsimulation models, input-output models, } \\
\text { BBN models, hybrid models. }\end{array}$ \\
\hline & Model purposes & $\begin{array}{l}\text { Ex-ante scenario analysis, ex-post scenario } \\
\text { analysis, relationships exploration }\end{array}$ \\
\hline & Model states & Static, dynamic. \\
\hline & Model temporal scales & $\begin{array}{c}\text { Short-term }(2020 \leqslant \mathrm{t} \leqslant 2030) \text {, medium-term } \\
(2031 \leqslant \mathrm{t} \leqslant 2050), \text { long-term }(2051 \leqslant \mathrm{t} \leqslant 2100) \text {. }\end{array}$ \\
\hline & Model spatial range & Global, regional, national, local. \\
\hline & Model sectors considered & Economic, social, environmental. \\
\hline & $\begin{array}{l}\text { Poverty and other SDGs } \\
\text { indicators }\end{array}$ & $\begin{array}{l}\text { Indicators (variables) proposed to measure } \\
\text { poverty and other SDGs. }\end{array}$ \\
\hline
\end{tabular}

Regarding to the model information, models for poverty scenario analysis were classified into seven types according to different modeling methods (Allen et al., 2016): (1) computable general equilibrium (CGE) models (Cantele et al.); (2) econometric models (Intriligator, 1983); (3) system dynamics (SD) models (Sterman, 2000); (4) microsimulation models; (5) input-output models (Ten Raa, 2009); (6) Bayesian belief network (BBN) models (Darwiche, 2009); and (7) hybrid models.

Each model targets one of the following three model purposes: ex-ante scenario analysis (i.e., estimation of future trends under different scenarios), ex-post scenario analysis (i.e., ex-post assessment of an event, policy, or behavior to analyze its influence), and relationships exploration (i.e., exploration of quantitative relationships between poverty and other factors under different scenarios). A model is considered to be static if it doesn't consider temporal factors and the process experienced, and dynamic if it can be used to examine the dynamic interactions in the system modeled and analyze the evolutionary process of these relationships over a time period. According to the maximum year $(t)$ simulated by dynamic models, temporal scales of models can be classified as short-term, medium-term, and long-term.

\section{Results}

\subsection{Bibliometric information}

Model-based poverty scenario analysis covered a wide range of research fields since the collected 144 papers were published in 96 journals. The number of publications reached a peak in 2018 (Figure 2a). Only three reviews were relevant to 
poverty-related scenario analysis (Figure 2b). These reviewed global modeling efforts of farmer household bio-economy models for assessing the effects of new technologies

171 on farming systems and livelihoods (Kruseman et al., 2020); the impacts of trade

172 liberalization on poverty based on CGE models (Anderson, 2020); and the scenario 173 modeling tools for assessing the implementation of national-scale SDGs (Allen et al., 174 2016).

175 The collected literature covered a wide range of research scales and areas. 176 Among 144 papers, more than half $(57.86 \%)$ were national scale, followed by local 177 (22.14\%) (Figure 2d). Countries that attracted the most attention are South Africa (10 178 cases) and China (9 cases) (Figure 3). Most studies (85\%) defaulted to the entire 179 population of the corresponding research area while only $15 \%$ considered specific 180 research objects.

181

182
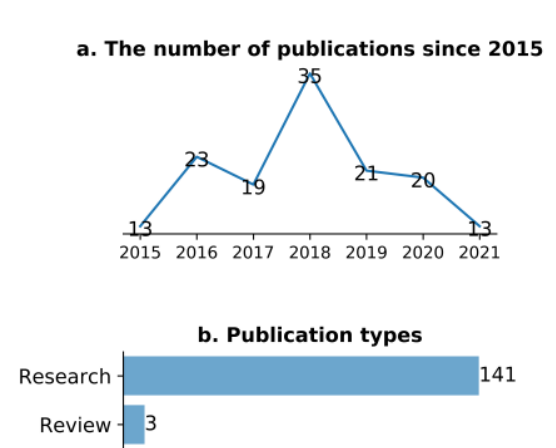
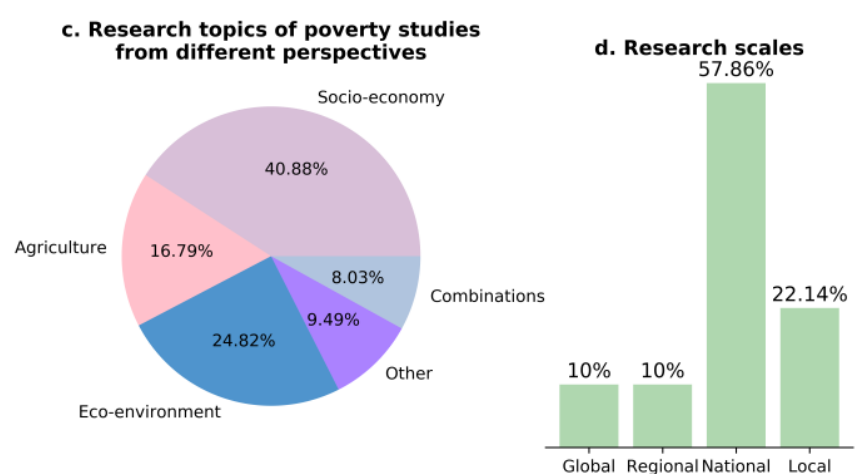

183 Figure 2. Distributions of the 144 selected papers in terms of (a) publication types, (b) 184 the number of publications per year, (c) topics, and (d) scales.

185

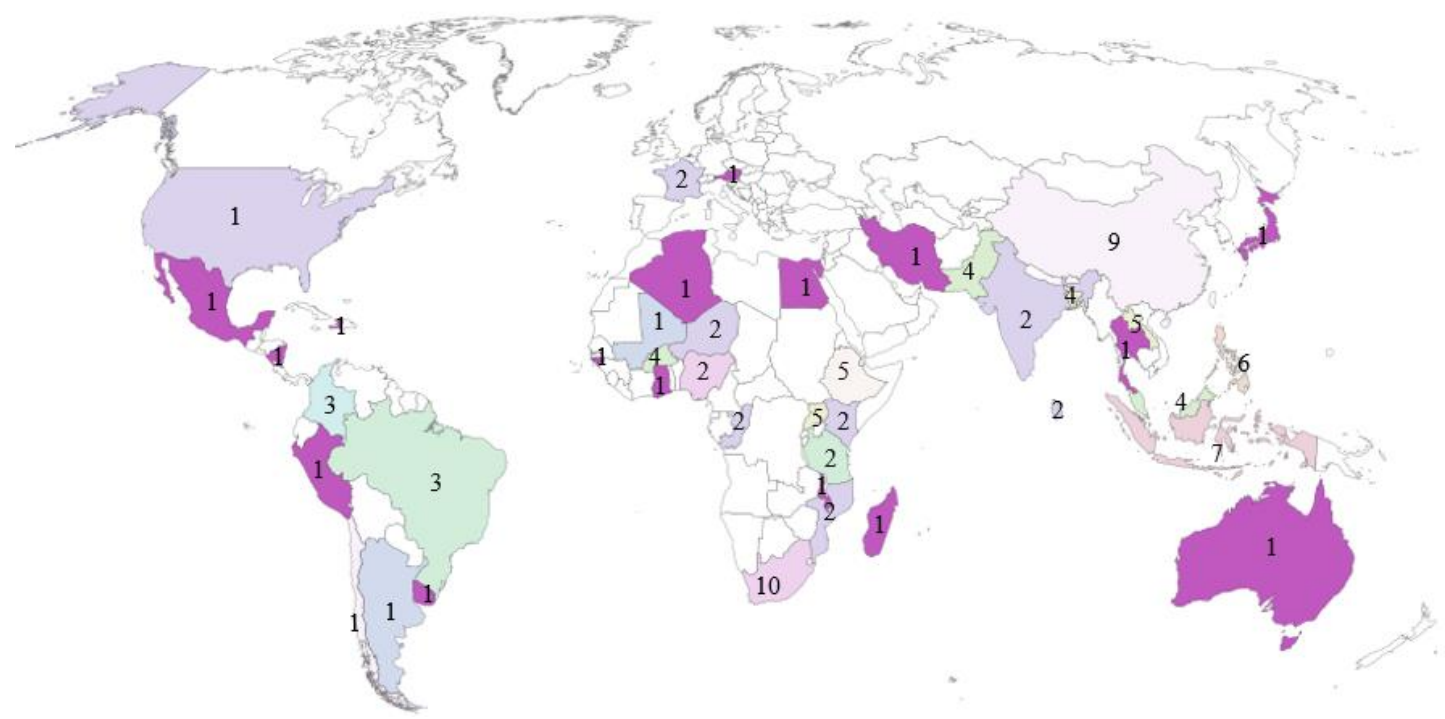

187 Figure 3. The number of national- and local-scale studies and their distribution.

188 Country with 10 studies: South Africa; Country with 9 studies: China; Country with 7 
studies: Indonesia; Country with 6 studies: Philippines; Countries with 5 studies:

190 Ethiopia, Laos, and Uganda; Countries with 4 studies: Bangladesh, Burkina Faso,

191 Malaysia, and Pakistan; Countries with 3 studies: Brazil, Colombia; Countries with 2

192 studies: Congo, France, India, Kenya, Tanzania, Mozambique, Niger, Nigeria and Sri

193 Lanka; Countries with only 1 study: Algeria, Argentina, Australia, Austria, Chile, Egypt,

194 Ghana, Guinea-Bissau, Haiti, Iran, Japan, Madagascar, Malawi, Mali, Mexico,

195 Nicaragua, Peru, Thailand, United States and Uruguay.

Different poverty research topics have been addressed in previous studies (Figure 2c). Most of them (41\%) investigated the impacts of socioeconomic activities on poverty from a variety of perspectives, including fiscal policies (e.g., cash transfer program (Gilliland et al., 2019), government redistributive policies (Mukarati et al., 2020; Salotti and Trecroci, 2018), tax reforms (Feltenstein et al., 2017; Llambi et al., 2016), public pension system (Inagaki, 2018), childcare policy (Cockburn et al., 2016)), trade liberalization policies (Liyanaarachchi et al., 2016), financial crises (Antoniades et al., 2020), and public investment adjustments in tourism (Banerjee et al., 2015), energy (Tiberti et al., 2017), and infrastructure (Medeiros et al., 2021). We found that economic growth, trade liberalization, and cash transfer have positive impacts on poverty reduction, in which the cash transfer has a significant impact in the short term, but has a limited role in the long run. A total of $26 \%$ of existing studies examined the connections between poverty and eco-environmental factors, such as climate policies (e.g., carbon tax) (Altieri et al., 2016), climatic risks (Aslam et al., 2018), natural resource degradation (Daregot et al., 2015), land deforestation (Siriban-manalang et al., 2016), and woodland ecosystem services (Zorrilla-Miras et al., 2018). These studies showed that eco-environmental deterioration increased poverty via increased food prices, decreased agricultural production and farmers' incomes. Moreover, some measures that could improve the environmental sustainability and enhance farmers' adaptability to climate change greatly reduced poverty, such as rational distribution of land, soil erosion management, and sewage treatment (X. Cheng et al., 2018).

The relationship between poverty and agriculture was also explored since the poorest households were thought to be more concentrated in agriculture (FAO, 2017). More than $16 \%$ of existing studies investigated the relationship and impacts of agriculture-related factors on poverty, which involve agricultural productivity variations (Zidouemba and Gerard, 2018), agricultural growth (Ndhleve et al., 2017), agricultural investment (Badibanga and Ulimwengu, 2020; Benfica et al., 2019), fertilizer use (van Wesenbeeck et al., 2021), and agricultural commodity price change (Solaymani, 2017; Solaymani and Yusoff, 2018). These studies suggested that poverty alleviation benefited from the growth of agricultural production and productivity, increased agricultural investment, appropriate amount and method of fertilizers application. In addition, around $9 \%$ of existing studies accounted for progress evaluation and interactions between SDGs (Allen et al., 2017; Allen et al., 2021), assessing the influence of various factors on poverty including health policies (Shrime et al., 2016), disease spread (Chitiga - Mabugu et al., 2021), technical efficiency (Islam 
and Haider, 2018), population aging (X. Wang et al., 2017), and urban characteristics

232 (Duque et al., 2015). Only 8\% of studies analyzed the combined effects of multiple 233 sectors on poverty, such as agriculture and climate (Montaud et al., 2017; Rosenzweig 234 et al., 2018), agriculture and ecology (X. Cheng et al., 2018), agriculture and education 235 (Karmozdi et al., 2020), and economy and ecology (Devarajan et al., 2015).

\subsection{Model information}

\subsubsection{Overview of model information}

In the selected studies, 138 papers presented models for poverty scenario analysis, while the remaining 6 papers were literature reviews or only introduced a conceptual model or framework. For these 138 papers, more than half of them (54.35\%) used national-scale models, while $23.19 \%, 12.32 \%, 10.14 \%$ applied local, regional, and global scale models, respectively (Figure 4c).

The most widely used model type is hybrid (55 in total) which integrate at least two model types, followed by CGE models (Figure 4a). The majority (46) of the hybrid models are the combination of CGE and microsimulation models. Both hybrid and CGE models were used mainly for ex-ante scenario analysis. There were 24 econometric models, most of which were developed for relationship analysis. The remaining models were all used for ex-ante scenario analysis, including 16 system dynamics models, 10 microsimulation models, 2 input-output models and 2 BBN models. In terms of model states, dynamic models were slightly more widely used than static models (Figure 4b). All SD and BBN models were dynamic.

For studies presenting dynamic models that explicitly defined a simulation period, 58\% were used for short-term (2020-2030) simulations, while only $12 \%$ were used for long-term (2051-2100) simulations (Figure 4d). Due to the close linkages between economy and poverty, all models considered the economy sector by modeling economy-related factors as variables and parameters in poverty scenario analysis, among which $31.16 \%$ of studies considered economic factors only while the remaining (68.84\%) further considered social and (or) environmental factors to enhance their comprehensive analysis capabilities (Figure 4e). 

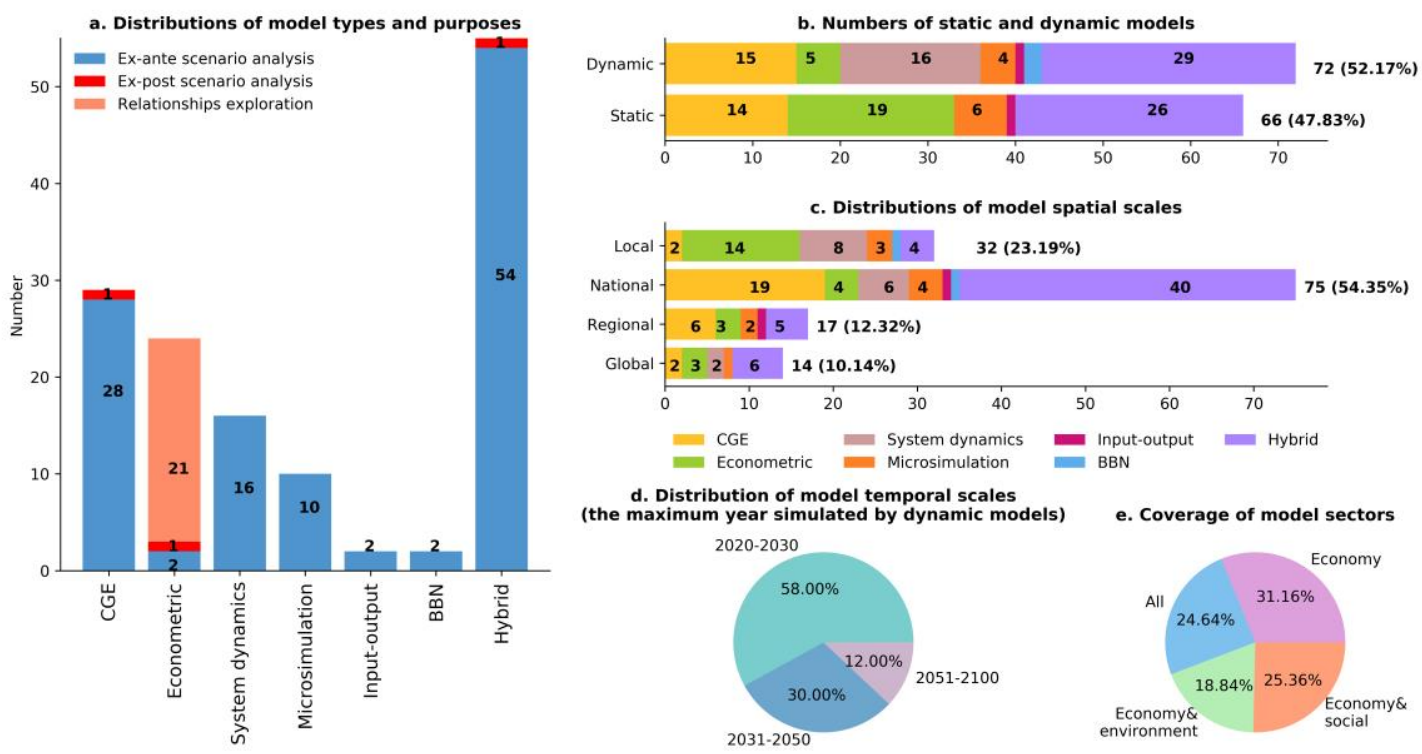

Figure 4. Overview of model information in selected studies.

\subsubsection{Poverty and other SDG indicators}

A total of 11 indicators were defined to measure poverty in model-based scenario analysis. More than two-thirds of studies only adopted one indicator, and the remaining used multiple indicators. These indicators are classified into direct and indirect indicators, and their usage counts are shown in Table 2.

The most commonly used indicator is the poverty rate, which is defined as the ratio of the number of people living below a given poverty line to the overall population. The ratio of people living below the poverty line has been calculated by income distribution (Cuaresma et al., 2018), household income (Lázár et al., 2020), household consumption (Ahmed et al., 2018), and growth of gross domestic product (GDP) (Ashimov et al., 2019; Ndhleve et al., 2017). Some models estimated poverty rates based on labor productivities and education levels (Cristea et al., 2020) or ecological factors such as topography, rainfall, and desertification (Zhou et al., 2020). The poverty population indicator is similar to the poverty rate, which is defined as the number of people living below a given poverty line. It has been obtained based on income per capita (Xin Cheng et al., 2018), economic growth (Supriyadi and Kausar, 2017), and the relationships between multiple factors (e.g., GDP, population, unemployment, agricultural investment) (Bafadal et al., 2020).

However, the two indicators mentioned above ignore the depth of poverty, signifying that the poverty rate remains constant if the poor become poorer (Foster et al., 2010). Some researchers thus used the poverty gap index to measure the depth of poverty, which is defined as the ratio by which the average income of the poor falls below the poverty line (C. Cororaton et al., 2018; Islam and Haider, 2018). Although the poverty gap index can indicate the depth of poverty, it cannot capture the inequality between the people living below the poverty line. The poverty severity index is thus 
proposed, which is defined as the average of the squared poverty gap ratio. It is a form of the weighted sum of the poverty gap, with the weight proportionate to the poverty gap. By squaring each poverty gap ratio of the poor who live below the poverty line, the larger the poverty gap of a person, the greater its weight in the poverty severity index calculation (Foster et al., 2010; Siriban-manalang et al., 2016). In addition, Duque et al. (2015) proposed a slums index to represent urban poverty by the number of slums in a city. Some researchers proposed multidimensional indicators to measure poverty from multiple dimensions of economy, health, education, basic living conditions, and environment, including multidimensional poverty index (Antoniades et al., 2020; W. Wang et al., 2018), binary poverty status (Nguyen and Nguyen, 2019) and poverty trap (Borgomeo, Hall, et al., 2018).

Indirect indicators (income returns, capital, and GDP) evaluate poverty though wealth data indicating the economic status of the population. The income returns indicator, representing the income return to unskilled labor, was seen as an alternative measurement of poverty (Jeong-Soo and Kyophilavon, 2015; Kyophilavong, Bin, et al., 2017), because the income gap is narrowed and poverty is reduced if the increased income return of unskilled labor is greater than it of skilled labor (Kyophilavong, Bin, et al., 2017). Indicators of capital (Garchitorena et al., 2017) and GDP (Glomsrød et al., 2016) assess poverty through their growth and distribution.

Table 2. Usage count of different poverty measurement indicators in the collected 308 literature.

\begin{tabular}{ccc}
\hline Categories & Indicators & Times used \\
\hline Poverty rate & 108 \\
Poverty gap & 38 \\
Poverty severity & 31 \\
Poverty population & 6 \\
Direct indicators & Multidimensional poverty & 5 \\
& index & 4 \\
& Binary poverty status & 2 \\
& Poverty trap & 1 \\
\hline Indirect indicators & Slums index & 2 \\
& Income returns & 1 \\
& Capital & 1 \\
\hline
\end{tabular}

In addition to poverty indicators, other SDG indicators have been considered in poverty scenario analysis models (Tables 3, 4). Variables for SDG 2 (zero hunger) (El Wali et al., 2021) and SDG 13 (climate change) (Marcinko et al., 2021) were most often used together with poverty. Only iSDG (MI, 2021) and IFs (Hughes, 2019) developed 
314 well-being), SDG 9 (industry, innovation, infrastructure), SDG 11 (sustainable cities 315 and communities), or SDG 16 (peace, justice, strong institutions) simultaneously. 316 Except for some indicators (e.g., maternal mortality for SDG 3, occupational accident 317 rate for SDG 8) that were developed to be completely consistent with SDGs agenda 318 (United Nations, 2021), many models used proxy indicators to measure SDGs (Table 319 4). For instance, crop yield could be used to measure SDG 2 (El Wali et al., 2021) while 320 agricultural water withdrawal could be used to measure SDG 6 (Byers et al., 2018).

321 Table 3. Models that considered synergies and trade-offs between SDG 1 and other 322 SDGs.

\begin{tabular}{|c|c|c|}
\hline Model types & Model names & SDGs coverage \\
\hline \multirow{3}{*}{ CGE models } & GTAP-POV a & SDG $1,7,8,13,17$ \\
\hline & MAMS $^{\mathrm{b}}$ & SDG $1,2,3,6$ \\
\hline & Inter-temporal Computable Equilibrium System ${ }^{\mathrm{c}}$ & SDG 1,10 \\
\hline \multirow{2}{*}{ SD models } & iSDG $^{d}$ & All 17 SDGs \\
\hline & Phosphorus supply ${ }^{\mathrm{e}}$ & SDG $1,2,5,6,8,12$ \\
\hline \multirow{5}{*}{ Hybrid models } & GIDD $^{\mathrm{f}}$ & SDG $1,4,8,10$ \\
\hline & IMPACT $^{g}$ & SDG $1,2,6,13,15$ \\
\hline & IFs ${ }^{h}$ & All 17 SDGs \\
\hline & An IAM framework ${ }^{\mathrm{i}}$ & SDG $1,2,10,13,14,15$ \\
\hline & An IAM framework ${ }^{j}$ & SDG $1,2,6,7,13,15$ \\
\hline
\end{tabular}

${ }^{a}$ Hertel et al. (2011). ${ }^{\mathrm{b}}$ Lofgren et al. (2013). ${ }^{\mathrm{c}}$ Campagnolo and Davide (2019). ${ }^{\mathrm{d}}$ MI (2021). ${ }^{\mathrm{e}}$ El Wali et al. (2021). ${ }^{\mathrm{f}}$

Bussolo et al. (2009). ${ }^{\mathrm{g}}$ Robinson et al. (2015). ${ }^{\mathrm{h}}$ Hughes (2018). ${ }^{\mathrm{i}}$ Marcinko et al. (2021). ${ }^{\mathrm{j}}$ Byers et al. (2018).

Table 4. Measurement indicators for other SDGs mentioned in Table 3.

\begin{tabular}{|c|c|c|}
\hline SDGs & Indicators aligned with the SDGs agenda & Proxy indicators \\
\hline SDG 2 Zero hunger & $\begin{array}{l}\text { Food security calculated by nutrition, life } \\
\text { expectancy, education, access to water. }\end{array}$ & $\begin{array}{l}\text { Crop yield, phosphorus } \\
\text { security }^{\text {a }}\end{array}$ \\
\hline $\begin{array}{l}\text { SDG } 3 \text { Good health and well- } \\
\text { being }\end{array}$ & $\begin{array}{l}\text { The mortality rate of children; maternal } \\
\text { mortality. }\end{array}$ & - \\
\hline SDG 4 Quality education & $\begin{array}{l}\text { Education penetration rate; educational level } \\
\text { of different groups of the population. }\end{array}$ & - \\
\hline SDG 5 Gender equality & $\begin{array}{l}\text { Female share of employment in managerial } \\
\text { positions, contraceptive prevalence rate. }\end{array}$ & $\begin{array}{l}\text { Employment rates for males } \\
\text { and females }{ }^{\text {a }}\end{array}$ \\
\hline SDG 6 Clean water and sanitation & $\begin{array}{c}\text { Proportion of access to safely managed water } \\
\text { source, access to safely managed sanitation } \\
\text { facility. }\end{array}$ & $\begin{array}{c}\text { The proportion of human } \\
\text { water demands relative to } \\
\text { available renewable surface } \\
\text { water supply, drought } \\
\text { intensity, non-renewable } \\
\text { groundwater, agricultural } \\
\text { water withdrawal }{ }^{\mathrm{b}} \text {. }\end{array}$ \\
\hline $\begin{array}{l}\text { SDG } 7 \text { Affordable and clean } \\
\text { energy }\end{array}$ & $\begin{array}{l}\text { Percentage of population with access to } \\
\text { electricity, renewable share in total final } \\
\text { energy consumption, energy intensity level of } \\
\text { primary energy. }\end{array}$ & $\begin{array}{l}\text { Fraction of access to clean } \\
\text { cooking }^{b}\end{array}$ \\
\hline $\begin{array}{l}\text { SDG } 8 \text { Decent work and } \\
\text { economic growth }\end{array}$ & $\begin{array}{l}\text { Real GDP per capita growth rate, GDP per } \\
\text { employed person growth rate, material }\end{array}$ & Livelihood of employees ${ }^{\text {a }}$ \\
\hline
\end{tabular}




\begin{tabular}{|c|c|c|}
\hline & $\begin{array}{c}\text { footprint index, domestic material } \\
\text { consumption, unemployment rate, share of } \\
\text { youth not in education employment or } \\
\text { training }\end{array}$ & \\
\hline $\begin{array}{l}\text { SDG } 9 \text { Industry, innovation, } \\
\text { infrastructure }\end{array}$ & $\begin{array}{l}\text { Rural access index, industry production, } \\
\text { industry employment as share of total } \\
\text { employment, } \mathrm{CO}_{2} \text { emissions per unit of value } \\
\text { added. }\end{array}$ & Rural roads ${ }^{c}$ \\
\hline SDG 10 Reduced inequality & $\begin{array}{l}\text { Bottom } 40 \% \text { income growth to average } \\
\text { income growth gap, proportion of population } \\
\text { below half median income. }\end{array}$ & $\begin{array}{l}\text { The Palma Ratio, income } \\
\text { inequality Gini index }{ }^{\mathrm{c}, \mathrm{d}}\end{array}$ \\
\hline $\begin{array}{l}\text { SDG } 11 \text { Sustainable cities and } \\
\text { communities }\end{array}$ & $\begin{array}{c}\text { Urban air quality, population affected by } \\
\text { disasters. }\end{array}$ & - \\
\hline $\begin{array}{l}\text { SDG 12 Responsible } \\
\text { consumption and production }\end{array}$ & $\begin{array}{l}\text { Material footprint, domestic material } \\
\text { consumption. }\end{array}$ & $\begin{array}{c}\text { Phosphorus balance in } \\
\text { circulation }^{\text {a }}\end{array}$ \\
\hline SDG 13 Climate change & $\begin{array}{l}\text { GHG emissions, population affected by } \\
\text { disasters }\end{array}$ & Heat events ${ }^{b}$ \\
\hline SDG 14 Life below water & $\begin{array}{l}\text { Proportion of fish stocks sustainably } \\
\text { exploited; proportion of territorial waters } \\
\text { effectively protected. }\end{array}$ & Fisheries changes $^{\mathrm{e}}$ \\
\hline SDG 15 Life on land & $\begin{array}{l}\text { Habitat degradation, proportion of territorial } \\
\text { areas effectively protected. }\end{array}$ & Land-use change ${ }^{\mathrm{h}}$ \\
\hline $\begin{array}{c}\text { SDG } 16 \text { Peace, justice, strong } \\
\text { institutions }\end{array}$ & $\begin{array}{c}\text { Bribery incidence, mortality rates caused by } \\
\text { violence. }\end{array}$ & - \\
\hline SDG 17 Partnerships & $\begin{array}{l}\text { proportion of domestic budget funded by } \\
\text { domestic taxes, grants as share of domestic } \\
\text { revenue. }\end{array}$ & Government investment $\mathrm{c}, \mathrm{i}$ \\
\hline \multicolumn{3}{|c|}{$\begin{array}{l}{ }^{a} \text { El Wali et al. (2021). }{ }^{b} \text { Byers et al. (2018). }{ }^{\mathrm{c}} \text { Hughes (2019). }{ }^{\mathrm{d}} \text { Campagnolo and Davide (2019). }{ }^{\mathrm{e}} \text { Marcinko et al. } \\
\text { (2021). }{ }^{\mathrm{h}} \text { Garchitorena et al. (2017). }{ }^{\mathrm{i}} \text { Hertel et al. (2011). }\end{array}$} \\
\hline
\end{tabular}

329 - Computable general equilibrium (CGE) models

330 Most CGE models aimed at the ex-ante analysis of possible future poverty 331 changes influenced by different social, economic, or natural changes (Figure 4a). Static 332 CGE models compared the poverty levels in the initial and final equilibrium states 333 affected by tax changes (Beckman et al., 2019), cash transfer programs (Yusuf, 2018), 334 trade liberalization (Jeong-Soo and Kyophilavon, 2015; Kyophilavong, Wong, et al., 335 2017), and agricultural productivity and efficiency improvements (Solaymani and 336 Yusoff, 2018). Dynamic CGE models simulated the dynamic impacts of various 337 influencing factors on poverty over time. These factors involve energy (Breisinger et 338 al., 2019), education subsidies changes (Mardones, 2015), agricultural productivity 339 (van Wesenbeeck et al., 2021) and investments (Badibanga and Ulimwengu, 2020; 340 Benfica et al., 2019), tax reforms (Mahadevan et al., 2017), carbon emissions (Altieri 341 et al., 2016; Campagnolo and Davide, 2019), and climate changes such as rainfall 342 shocks (Borgomeo, Vadheim, et al., 2018). However, around two-thirds of them were 343 only applied to project the trends between 2020-2030, and the remaining was applied 344 to projections between 2031-2050. 
In previous studies using CGE models, about two-fifths $(37.93 \%)$ of previous studies involved economic variables only in CGE models, $24.14 \%$ and $27.59 \%$ of them contained economic and social, and economic and environmental variables, respectively, while the remaining $10.34 \%$ involved economic, social, and environmental variables. Common economic variables include labor types, trade activities, capital classification, GDP and income, government financial allocation, agricultural products, and productivity (Badibanga and Ulimwengu, 2020; Borgomeo, Vadheim, et al., 2018). The social variables most often modeled include population growth, employment and unemployment, and education development (Breisinger et al., 2019; Mardones, 2015). The environmental variables mainly are land types and shares, greenhouse gas emissions and energy access (Campagnolo and Davide, 2019; Fujimori et al., 2020).

- Econometric models

Most applications of econometric models for poverty analysis aimed to investigate the connections of poverty and various influencing factors modeled in the entire system (Figure 4a). On one hand, relationships between poverty and socioeconomic activities (e.g., tourism economy (Supriyadi and Kausar, 2017), financial crises (Antoniades et al., 2020), urban fabric characteristics (Duque et al., 2015)) were examined to analyze their impacts. Bafadal et al. (2020) constructed an econometric model to assess government expenditure and its impact on agricultural output performance and poverty. On the other hand, linkages between poverty and natural resource degradation (Daregot et al., 2015) and the vulnerability of households to climatic disasters (Taupo et al., 2018) were identified. In addition to relationship analysis, two global multi-country econometric models were utilized for ex-ante analysis, one of which only predicted the consequences of various economic measures to fight poverty until 2020 (Ashimov et al., 2019), and the other evaluated absolute poverty changes at the global level under different shared socioeconomic pathways until 2030 (Cuaresma et al., 2018).

Static and dynamic econometric models introduced panel data (a set of survey data that occur at the same time) and time-series historical data as sample data, respectively, to estimate model parameters for poverty analysis. Most econometric models are static (Figure $4 \mathrm{~b}$ ). The economic model variables that are often considered in econometric models for poverty analysis include capital, GDP, income, labor categories, agricultural efficiency, government investments, and trade activities. Education level, employment situation, population growth, and demographic characteristics are common social variables modeled in econometric models. Several environmental variables were also constructed in four econometric models, such as ecological situations (e.g., degree of desertification and soil erosion, precipitation, geological disasters) (Zhou et al., 2020), and accessibility of natural resources like water, energy, and land (Abraham, 2018; Daregot et al., 2015; W. Wang et al., 2018). 
Based on their dynamic and evolutionary characteristics, SD models in the selected literature were all used to project possible future trends of poverty under different scenarios, which can be classified into three groups according to three different modeling themes. The first group, also the most researched, is the nexus of ecosystem, economy, and poverty (Cheng et al., 2019; Garchitorena et al., 2017). For example, Grace et al. (2017) applied a national-scale SD model to illustrate that poverty traps may arise through the inter-relationships between ecosystem services damage, health, and well-being outcomes. Xin Cheng et al. (2018) established the interaction mechanism between the ecological environment, disasters, and poverty in China's reservoir regions, and simulated the effects of different environmental protection and poverty reduction strategies on poverty eradication.

The second group focused on the relationships between agriculture-related influencing factors and poverty. Karmozdi et al. (2020) constructed a local sustainable rural development model to simulate the impact of agricultural support, nonagricultural support, and environmental education on multidimensional poverty. Brinkmann et al. (2021) developed a local SD model for projecting possible trends in farmer crop management to 2045 and simulating their impacts on the family economy and environment. Ndhleve et al. (2017) investigated causality between agricultural public expenditure, agricultural growth, and poverty, and the driving factors of poverty reduction in South Africa, and found that investments in agricultural research, rural infrastructure and rural education had the greatest impact on poverty alleviation.

The third group analyzed the influence of socioeconomic scenarios on poverty. An integrated iSDG-Fiji model was constructed to perform a national-scale scenario analysis for Fiji (Allen et al., 2021), with a business-as-usual future scenario and six alternative scenarios within global Shared Socioeconomic Pathways, which evaluated the progress of each SDG by 2030 and the trends of environmental changes by 2050 in terms of planetary boundaries. Similarly, an integrated iSDG-Australia model was developed to project the future performance and assess the progress of 17 SDGs under four development scenarios by 2030 in Australia (Allen et al., 2019).

\section{- Microsimulation models}

Microsimulation models were usually used to analyze the impacts of economic and climate changes on poverty. A tax-benefit model EUROMOD, a form of microsimulation model, was applied to analyze the impact of subsidy reform policies on finances, income distribution, and poverty risks (Fuchs et al., 2017), and simulate a set of scenarios of increasing subsidies for childcare and mothers' employment and estimate their impacts on child poverty (Hufkens et al., 2020). The impact of climate change on household-level poverty by 2030 was assessed by combining the physical impact assessments of climate change in various sectors with a global database of household surveys in 92 countries (Hallegatte and Rozenberg, 2017). Agent-based models, as another type of microsimulation models, were implemented to evaluate the impact of healthcare policies on health, poverty and income distribution by 2050 in 
Uganda (Shrime et al., 2016), and explored the long-term interdependence between agroforestry adoption decisions of farmers, poverty, and ecological environment in Indonesian rural areas (Nöldeke et al., 2021).

\section{- $\quad$ Bayesian belief network (BBN) models}

$\mathrm{BBN}$ models are suitable to estimate the probability of possible causes, consequences, or subsequent events from learning from data, which have been used to simulate the impact of agricultural policy on poverty in Ghana (Banson et al., 2016) and analyze the contribution of forest ecosystem services to rural household assets and multidimensional poverty in Southern Mozambique during 2015-2035 (Zorrilla-Miras et al., 2018).

\section{- Input-output models}

Only two studies applied input-output models for poverty scenario analysis. Input-output models were utilized to evaluate the effects of different carbon tax rates on income distribution and poverty in Mexico by combining with household survey data (Renner, 2018), and the potential impact of climate policies and employment on poverty by 2030 in more than 40 countries (Malerba and Wiebe, 2021).

\section{- Hybrid models}

Most hybrid models are CGE with microsimulation analysis (CGE-MS) models, with the modeling framework combines macro-CGE models with microsimulation models to capture the impact of macro-shocks on micro-distributions (Bussolo and Cockburn, 2010). CGE-MS models use the output of the CGE model as the input of the microsimulation model to analyze the micro impacts on income distribution and poverty from different scenarios, including taxes reforms (DIZON, 2021; Mohammed, 2018), cash transfer programs (Cury et al., 2016), trade policies (Boysen and Matthews, 2017; Shuaibu, 2017), agricultural policies (Boysen et al., 2016; C. B. Cororaton and Yu, 2019), energy subsidies (Cockburn et al., 2018), health (Chitiga - Mabugu et al., 2021; Kabajulizi et al., 2017), and ecological changes (C. Cororaton et al., 2018; Siriban-manalang et al., 2016).

Only several hybrid models integrate other model types. A local integrated assessment model, combining an improved FAO CROPWAT model for agricultural yields estimation and an agent-based model for wellbeing projection, was applied to predicting poverty and inequality under different climate and socio-economic scenarios by 2100 in the southwestern coastal area of Bangladesh (Lázár et al., 2020). A static local hybrid model that combined four climate models was employed to study the pressures on food security, multidimensional poverty, and environment brought by climate changes in 2035, 2065 and 2085 in southern Pakistan (Aslam et al., 2018). Belem and Saqalli (2017) proposed a national comprehensive model combining system dynamics, Bayesian networks, and agent-based techniques to assess the impact of climate change, agricultural ecosystems, and demographic transitions on a West African country's ecosystem services, poverty reduction, and food self-sufficiency. Furthermore, 
several global hybrid models were utilized to study the consequences of various climate change scenarios (Byers et al., 2018; Rosenzweig et al., 2018). The most famous one is the International Futures (IFs) model, which is a large-scale integrated assessment model with interconnected sub-models of economy, population, education, agriculture, energy, and environment. The IFs model was adopted to explore the possible potential progress in poverty eradication in fragile countries by 2030 (Milante et al., 2016) and analyze the progress of SDGs and the potential for economic growth by 2100 (Hughes and Narayan, 2021).

\section{Discussion}

\subsection{Model comparison}

Table 5 summarizes the pros and cons of models commonly used for poverty scenario analysis. CGE models can construct linkages of various economic sectors and industries to reflect a coordinated interaction mechanism within the economy. Due to the theoretical foundation of the general equilibrium modeling method, CGE models have some limitations. First, they rely on the assumption that the economy will move toward an equilibrium state (an ideal state), which may be inconsistent with the actual economic situation. Second, they cannot respond effectively to future uncertainties (e.g., the unexpected occurrence of the COVID-19 pandemic, drastic changes of economic structure) because the trend relies on a large amount of historical data (e.g., social accounting matrix), which limits the understanding of poverty issues that arise over time from the interactions of multiple sectors. Third, some global CGE models that focus on long-term poverty scenario analysis are inherently difficult to verify, due to the difficulty in collecting required high-quality data for all countries (Jin et al., 2017). For econometric models, model verification is relatively easy, because it is usually carried out together with the parameter estimation to maximize the goodness of fit of the model. However, they are only suitable for short-term poverty projections and the situation of which the future socioeconomic trends are in line with past experience. In the case of rapid socioeconomic, the model effectiveness in the projection of poverty indicators will be seriously affected (Rey, 2000). SD models can track cause and effect, allowing the exploration of complex systems with poverty feedback loops and promoting the understanding of the causes and influences of poverty. SD models can be used for poverty scenario analysis outside of the experience of historical data, but they have some parameters and functional forms that are difficult to estimate. Their verification is also complicated, and not only involves assessing the quality of parameter estimations using a variety of data, but also evaluates the effectiveness of model structure (Jin et al., 2017). Microsimulation models can effectively simulate the impact of different poverty alleviation policies on different groups or individuals, but they require more behavioral assumptions and more accurate microeconomic data compared with traditional macroeconomic models (Ballas et al., 2013). 
detailed industry information, and data are required to show the income and expenditure

508 of each economic sector to support poverty analysis. However, they are difficult to split 509 and integrate relevant data reflecting the industrial linkages among regions and 510 countries under some circumstances. Similar to other model types that rely heavily on 511 historical data, they cannot effectively respond to future uncertainties (Rey, 2000). BBN 512 models use conditional probability to express the causal and conditional relationships 513 between poverty and various elements, which can learn and deduce the probability of 514 occurrence of some outcomes under conditions of limited, incomplete, and uncertain 515 information. However, they are constructed based on the assumption of sample attribute 516 independence, and the model effectiveness gets worse if the sample data violate this 517 assumption (Oladokun, 2014). Hybrid models encompass combinations of a variety of 518 models and thus can conduct both macro and micro poverty scenario analysis, cover 519 wider sectors and have higher applicability for poverty in more complicated systems. 520 However, using hybrid models have to face the difficulties of complicated model 521 development and evaluation as well as the higher unavailability of historical data.

522 Table 5. Advantages and disadvantages of various models commonly used for poverty 523 scenario analysis.

\begin{tabular}{|c|c|c|}
\hline Model types & Model advantages & Model disadvantages \\
\hline CGE models & Link various economic sectors and industries. & $\begin{array}{l}\text { Relying on the assumption of equilibrium; } \\
\text { unable to respond effectively to future uncertainties; } \\
\text { difficult to verify the global model and organize the data; }\end{array}$ \\
\hline $\begin{array}{l}\text { Econometric } \\
\text { models }\end{array}$ & Easy to verify the model by fitting historical data. & $\begin{array}{l}\text { Suitable for short-term development research instead of } \\
\text { long-term research; } \\
\text { unable to respond effectively to future uncertainties. }\end{array}$ \\
\hline SD models & $\begin{array}{l}\text { Exploration of causal mechanism and dynamic } \\
\text { complex relationships; } \\
\text { can be used for scenario analysis beyond the trend } \\
\text { of historical data. }\end{array}$ & $\begin{array}{l}\text { Difficult to obtain values of some parameters; } \\
\text { difficult to evaluate models' effectiveness. }\end{array}$ \\
\hline $\begin{array}{l}\text { Microsimulation } \\
\text { models }\end{array}$ & $\begin{array}{l}\text { Analyze the impacts on different populations and } \\
\text { even individuals. }\end{array}$ & $\begin{array}{l}\text { Need more behavioral assumptions and more accurate } \\
\text { and true microeconomic data; } \\
\text { difficult to evaluate models' effectiveness. }\end{array}$ \\
\hline $\begin{array}{l}\text { Input-output } \\
\text { models }\end{array}$ & $\begin{array}{l}\text { Reflect the structural relationships of industries by } \\
\text { detailed industry information. }\end{array}$ & $\begin{array}{l}\text { Difficult to split and integrate relevant data reflecting the } \\
\text { industrial linkages among regions and countries; } \\
\text { unable to respond effectively to future uncertainties. }\end{array}$ \\
\hline BBN models & Causal and conditional relationships exploration. & Use the hypothesis of sample attribute independence. \\
\hline Hybrid models & $\begin{array}{l}\text { Macro and micro combination; } \\
\text { wider sectoral coverage; } \\
\text { suitable for studying complex issues. }\end{array}$ & $\begin{array}{l}\text { More complicated model development; } \\
\text { more data demand; } \\
\text { difficult to evaluate models' effectiveness. }\end{array}$ \\
\hline
\end{tabular}

In summary, it is recommended to use CGE or econometric models if a study focuses more on economic activities and poverty. Input-output models are more suitable

526 to explore the relationship between poverty and each single industry (e.g., agriculture, 
forestry, fishery, manufacturing, transportation). Microsimulation models are

528 appropriate to conduct the poverty analysis at the micro level (e.g., individuals, communities). SD and BBN models are the better choice if the dynamic causal mechanisms covering poverty and multiple other sectors need to be explored. Hybrid models can be utilized to research poverty in complex systems with dynamic causal mechanisms, relationships of various sectors and industries by combining multiple types of models at macro and micro levels.

\subsection{Representative models}

We derived seven representative models (Table 6) from more than 100 candidate scenario analysis models in the literature. A model is regarded as representative if it meets the following standards: (1) The model can be used for different countries or global setting instead of for only one country; (2) The model is developed by an authoritative organization (i.e., international organizations or well-known universities);

540 (3) An introductory document or official website for this model is accessed publicly.

541 Representative models include two CGE models, one SD model, one microsimulation 542 model, and three hybrid models.

One CGE model, the Global Trade Analysis Project (GTAP) model embedding 544 a poverty module (GTAP-POV), is an extension of the GTAP model to analyze the 545 dynamic impact of global economic and environmental changes on national poverty, 546 which was developed by an alliance composed of institutions such as the World Bank,

547 World Trade Organization, European Commission, Organization for Economic 548 Cooperation and Development (OECD), and International Monetary Fund (Hertel et al., 549 2011). GTAP is a multi-region and multi-sector CGE model, accompanied by a multi550 country input-output table that includes production, consumption, bilateral trade and 551 transportation data. Another CGE model, Maquette for MDG Simulations (MAMS), is 552 a dynamic country-level model designed by the World Bank to analyze the national 553 progress for the Millennium Development Goals (MDGs) of poverty, health, education, 554 water and sanitation (Lofgren et al., 2013). MAMS was applied for World Bank country 555 analysis, such as Public Expenditure Reviews and Poverty Assessments (Hans and 556 Carolina, 2009).

557 Table 6. Representative poverty scenario analysis models and their characteristics.

\begin{tabular}{|c|c|c|c|c|c|}
\hline $\begin{array}{c}\text { Model } \\
\text { types }\end{array}$ & $\begin{array}{l}\text { Model } \\
\text { names }\end{array}$ & $\begin{array}{l}\text { Model purpose } \\
\text { and states }\end{array}$ & $\begin{array}{l}\text { Spatial and temporal } \\
\text { scales }\end{array}$ & Main variables coverage & $\begin{array}{c}\text { Poverty } \\
\text { measurement }\end{array}$ \\
\hline \multirow{2}{*}{$\begin{array}{l}\text { CGE } \\
\text { models }\end{array}$} & $\begin{array}{l}\text { GTAP- } \\
\text { POV }\end{array}$ & $\begin{array}{l}\text { ex-ante scenario } \\
\text { analysis; } \\
\text { dynamic } \\
\end{array}$ & $\begin{array}{c}\text { Global, regional, national } \\
\text { (140 regions); } \\
\text { up to } 2100 \\
\end{array}$ & $\begin{array}{l}\text { GDP, income distribution, } \\
\text { energy, climate, trade, } \\
\text { government finance, etc. }\end{array}$ & $\begin{array}{l}\text { PR calculated } \\
\text { by income }\end{array}$ \\
\hline & MAMS & $\begin{array}{l}\text { ex-ante scenario } \\
\text { analysis; } \\
\text { dynamic } \\
\end{array}$ & $\begin{array}{l}\text { National (developing } \\
\text { countries); } \\
\text { up to } 2030 \\
\end{array}$ & $\begin{array}{l}\text { GDP, income, education, health, } \\
\text { water, sanitation, trade, } \\
\text { government finance, etc. }\end{array}$ & $\begin{array}{l}\text { PR calculated } \\
\text { by income or } \\
\text { consumption }\end{array}$ \\
\hline $\begin{array}{c}\mathrm{SD} \\
\text { models }\end{array}$ & iSDG & $\begin{array}{l}\text { ex-ante scenario } \\
\text { analysis; }\end{array}$ & National; & $\begin{array}{l}\text { GDP, income, population, } \\
\text { health, education, agriculture, }\end{array}$ & $\begin{array}{l}\text { PR calculated } \\
\text { by income }\end{array}$ \\
\hline
\end{tabular}




\begin{tabular}{|c|c|c|c|c|c|}
\hline & & dynamic & up to 2050 & $\begin{array}{l}\text { land, water, climate, energy, } \\
\text { infrastructure, etc. }\end{array}$ & \\
\hline $\begin{array}{l}\text { Micro- } \\
\text { simulation } \\
\text { models }\end{array}$ & $\begin{array}{l}\text { EUROM } \\
\text { OD }\end{array}$ & $\begin{array}{l}\text { ex-ante scenario } \\
\text { analysis; } \\
\text { static } \\
\end{array}$ & $\begin{array}{l}\text { Regional, national (EU } \\
\text { countries, United } \\
\text { Kingdom) }\end{array}$ & $\begin{array}{l}\text { GDP, income, households, } \\
\text { government finance, etc. }\end{array}$ & $\begin{array}{l}\mathrm{PR} \text { calculated } \\
\text { by income }\end{array}$ \\
\hline \multirow{3}{*}{$\begin{array}{l}\text { Hybrid } \\
\text { models }\end{array}$} & GIDD & $\begin{array}{l}\text { ex-ante scenario } \\
\text { analysis; } \\
\text { dynamic } \\
\end{array}$ & $\begin{array}{l}\text { Global, regional, national } \\
\text { (121 countries); } \\
\text { up to } 2100 \\
\end{array}$ & $\begin{array}{l}\text { GDP, income, trade, education, } \\
\text { etc. }\end{array}$ & $\begin{array}{l}\text { PR calculated } \\
\text { by income }\end{array}$ \\
\hline & IMPACT & $\begin{array}{l}\text { ex-ante scenario } \\
\text { analysis; } \\
\text { dynamic } \\
\end{array}$ & $\begin{array}{l}\text { Global, regional, national } \\
\text { (159 countries); } \\
\text { up to } 2100 \\
\end{array}$ & $\begin{array}{l}\text { GDP, income, climate, } \\
\text { agriculture, water, food supply, } \\
\text { demand, trade, prices, land use, } \\
\text { nutrition and health, etc. }\end{array}$ & GDP \\
\hline & IFs & $\begin{array}{l}\text { ex-ante scenario } \\
\text { analysis; } \\
\text { dynamic }\end{array}$ & $\begin{array}{l}\text { Global, regional, national } \\
\text { (186 countries); } \\
\text { up to } 2100\end{array}$ & $\begin{array}{l}\text { GDP, income, population, } \\
\text { education, agriculture, } \\
\text { technology, government finance, } \\
\text { international politics, health, } \\
\text { energy, water infrastructure, } \\
\text { environment, governance, etc. }\end{array}$ & $\begin{array}{l}\text { PR calculated } \\
\text { by income }\end{array}$ \\
\hline
\end{tabular}

The integrated Sustainable Development Goals (iSDG) is a SD model 559 constructed by Millennium Institute (MI, 2021). This model extends the concept of 560 CGE models to a wider range of dynamic connections and policy issues to support 561 national development planning and sustainable scenarios analysis, and explore the 562 impact of policies on the country's progress in achieving all SDGs. iSDG has been used 563 to formulate many countries' reports of SDGs' achievement progress (MI, 2021). A 564 static tax-benefits model EUROMOD is a microsimulation model proposed by the 565 European Union (EU), which can be used to analyze and compare the impact of 566 different taxes and benefits policies on poverty, inequality and budget at individuals 567 and households levels for each EU country and the United Kingdom (Sutherland and 568 Figari, 2013).

Global Income Distribution Dynamics (GIDD) is developed by the World Bank, 570 which is a global hybrid model with the macro-micro framework integrating a dynamic 571 CGE model and a microsimulation model. It could be used to analyze the impact of 572 different global policies scenarios on global economic growth, income distribution and 573 poverty (Bussolo et al., 2009). GIDD has been adopted widely in previous studies, such 574 as working papers and reports by OECD (Bourguignon and Bussolo, 2013). The 575 International Model for Policy Analysis of Agricultural Commodities and Trade 576 (IMPACT) proposed by the International Food Policy Research Institute (Robinson et 577 al., 2015), is also a global hybrid model integrating climate models, crop simulation 578 models, water models with a core global partial equilibrium multi-market economic 579 model. IMPACT has been applied to addressing how to reduce poverty and feed the 580 world while protecting natural resources in the future (Rosegrant et al., 2017), and also 581 used in the World Bank's reports for interdisciplinary analysis (World Bank, 2007). 582 International futures (IFs), proposed by the Pardee Center for International Futures in 583 the University of Denver (Hughes, 2019), is a large-scale, multi-issue long-term 584 integrated assessment model integrating multiple sub-models, including a general 
equilibrium economic sub-model, and sub-models of population, agriculture, education, energy, environment, and international politics (Hughes, 2019). IFs allows projecting the progress of all SDGs in 186 countries influenced by different economic, social and environmental changes throughout the 21st century, which has been utilized in many international reports like the United Nations Human Development Report and the Global Environment Outlook (Hughes, 2018).

\subsection{Modelling synergies and trade-offs between SDG 1 and other SDGs}

As a complex social issue, poverty eradication is inseparable from the interaction of the entire socioeconomic and environmental system (e.g., socioeconomic changes, demographics, land, food, energy and climate). The SDG framework integrates key environmental, social and economic goals to promote sustainable development, and almost all SDGs influence poverty elimination (Kroll et al., 2019; Pradhan et al., 2017). For instance, taking unsustainable actions (e.g., a large amount consumption of fossil fuels to satisfy the energy demand for rapid economic growth, vigorous industry development without paying attention to environmental governance) to promote economic growth and further eliminate poverty may be the most convenient and quickest way in the short term (Adger and Winkels, 2014). However, some side effects will appear over a longer time horizon, such as increased greenhouse gas emissions and climate changes (SDG 13) (Bowles et al., 2014), environmental degradation (e.g., water (SDG 6) and soil (SDG 15) pollution, deforestation), biodiversity loss (SDG 15), and increased risk of pandemics (SDG 3) (Schleicher et al., 2018). In the long run, these side effects will affect economic growth (SDG 8) and then eventually increase poverty (SDG 1).

However, most existing models for poverty scenario analysis overlooked the importance of synergies and trade-offs among SDGs (section 3.2.2). On one hand, only ten models clearly developed variables for other SDGs, and only iSDG and IFs had variables for all 17 SDGs. SDGs 5-7, 9, 10, 12, and 14 were measured by proxy indicators, indicators that were fully in line with the sub-goals of these SDGs have not been constructed in collected models. Although other SDGs could be evaluated by indicators that were consistent with the SDGs agenda, one SDG contains multiple subgoals and quite a few sub-goals have not been modelled. On the other hand, although some models covered some variables that could be used to evaluate some SDGs, the mechanisms of their interactions are still elusive. Analysis of these mechanisms by cross-disciplinary innovation is critical to understand their synergies and trade-offs, which need various challenging efforts, including integrating various systems involved in the economy, society and the environment, and identifying the interrelated factors and behaviors in systems, and then establishing their dynamic relationships. These efforts will promote a comprehensive understanding of the evolution mechanism of poverty in a complex system instead of the simple behavioral association between poverty and certain factors, which ultimately help uncover better poverty reduction strategies with consideration of synergies and trade-offs for other SDGs. 
This paper reviewed 144 papers on model-based poverty scenario analysis. We classified these models into seven types, including computable general equilibrium, econometric models, system dynamics models, microsimulation models, input-output models, Bayesian belief network models, and hybrid models. These models were used for ex-ante scenario analysis, ex-post scenario analysis, and relationships exploration. We also identified seven representative poverty scenario analysis models. We found the following research gaps based on the review of bibliometric and model information, and the discussions on different model types and interactions between poverty and other SDGs.

(1) Around $80 \%$ of previous studies were carried out at national and local levels and models that could be used for medium- and long-term poverty simulations were very limited. However, in the context of increasing international cooperation and integration, poverty research from global to local scales is indispensable. It is conducive to understanding the evolution mechanism of poverty and their interactions with other SDGs and other related international agendas (e.g., the Paris Agreement), guiding global to local poverty strategies in a long-term perspective (Hughes et al., 2015).

(2) Poverty scenario analysis was mainly carried out from the single perspective of the economy, eco-environment, and agriculture, while comprehensive analyses that integrate multiple sectors (e.g., economic, social, and environmental) was seldom reported. Few models can address synergies and trade-offs between SDG 1 and other SDGs, but the interactions between poverty and other SDGs and their potential impacts are essential for reducing poverty and the resulting negative impacts (De Neve and Sachs, 2020), and poverty alleviation needs to be dealt with scientifically in a more comprehensive and integrated way (Adger and Winkels, 2014).

(3) The hybrid models used in poverty scenario analysis were mainly the integration of CGE and microsimulation models. The advantages of these models were not fully reflected for modelling dynamic causal mechanisms and multiple sectors relationships in complex systems.

(4) The poverty rate was the most widely used indicator to measure poverty in previous studies. However, due to the complexity of poverty and its diverse driving factors, this indicator cannot represent the diverse information of poverty, such as the depth and inequality of poverty.

As a result of the literature review about model-based poverty scenario analysis, some suggestions for future research are provided below to fill up the research gaps in existing studies.

(1) It is desirable to develop effective scenario analysis models for more medium- and long-term simulations of poverty changes under different future scenarios, especially global and regional models for understanding the evolution of global or regional poverty. 
(2) The second promising direction is to develop scenario analysis models covering multiple sectors and a broad range of variables for these sectors so that the combined effects of multiple poverty alleviation policies can be evaluated. These variables include economic growth, population, education, health, agriculture, climate change, land use, water use, and energy use.

(3) It will be helpful to enhance the modeling of synergies and trade-offs between poverty and other SDGs, particularly with the relevant SDGs that are considered to have significant synergies or trade-offs (e.g., SDGs 2-3, SDGs 7-9, SDG 13) (Griggs et al., 2017; Kroll et al., 2019), or with the SDGs that are rarely modeled (e.g., SDGs 4-5, SDGs 11-12, SDG 14).

(4) To model complex systems effectively, it is critical to develop hybrid models by the integration of multiple single models that can complement with each other. For example, integrating system dynamic models with CGE concepts is capable of modelling dynamic causal mechanisms and multiple sectoral linkages.

(5) To measure poverty in a comprehensive manner, future work could measure

\section{Acknowledgments}

This work was supported by the General Program of National Natural Science Foundation of China (Grant No.s, 72171159 and 71872118), Sichuan University (Grant No., SKSYL201819), and China Scholarships Council (Grant No., 202006240133). The authors declare that they have no known competing financial interests or personal relationships that could have appeared to influence the work reported in this paper.

\section{CRediT authorship contribution statement}

Qi Liu: Conceptualization, Methodology, Visualization, Writing - original draft. Zhaoxia Guo: Conceptualization, Methodology, Writing - review \& editing. Gao Lei and Yucheng Dong: Methodology, Writing - review\& editing. Jing Yang: Visualization, Writing - review \& editing. Enayat A. Moallemi, Sibel Eker, Michael Obersteiner and Brett A. Bryan: Writing - review\& editing. Xiaofeng Li: Supervision, Project administration.

\section{References}

Abraham, T. W. (2018). Estimating the effects of financial access on poor farmers in rural northern Nigeria. Financial Innovation, 4(1), 1-20. https://doi.org/10.1186/s40854$\underline{018-0112-2}$

701 Adger, W. N., \& Winkels, A. (2014). Vulnerability, poverty and sustaining well-being. In 
Ahmed, S. A., Barış, E., Go, D. S., Lofgren, H., Osorio-Rodarte, I., \& Thierfelder, K. (2018). Assessing the global poverty effects of antimicrobial resistance. World Development, 111, 148-160. https://doi.org/10.1016/j.worlddev.2018.06.022

Allen, C., Metternicht, G., \& Wiedmann, T. (2016). National pathways to the Sustainable Development Goals (SDGs): A comparative review of scenario modelling tools. $\begin{array}{lllll}\text { Environmental Science } \quad \& \quad \text { Policy, } & 66, & 199-207 .\end{array}$ https://doi.org/10.1016/j.envsci.2016.09.008

Allen, C., Metternicht, G., \& Wiedmann, T. (2017). An iterative framework for national scenario modelling for the Sustainable Development Goals (SDGs). Sustainable Development, 25(5), 372-385. https://doi.org/10.1002/sd.1662

Allen, C., Metternicht, G., Wiedmann, T., \& Pedercini, M. (2019). Greater gains for Australia by tackling all SDGs but the last steps will be the most challenging. Nature Sustainability, 2(11), 1041-1050. https://doi.org/10.1038/s41893-019-0409-9

Allen, C., Metternicht, G., Wiedmann, T., \& Pedercini, M. (2021). Modelling national transformations to achieve the SDGs within planetary boundaries in small island developing States. Global Sustainability, 4(e15), 1-13. https://doi.org/10.1017/sus.2021.13

Altieri, K. E., Trollip, H., Caetano, T., Hughes, A., Merven, B., \& Winkler, H. (2016). Achieving development and mitigation objectives through a decarbonization development pathway in South Africa. Climate Policy, 16(sup1), S78-S91. https://doi.org/10.1080/14693062.2016.1150250

Alwang, J., Gotor, E., Thiele, G., Hareau, G., Jaleta, M., \& Chamberlin, J. (2019). Pathways from research on improved staple crop germplasm to poverty reduction for smallholder farmers. Agricultural Systems, 172, 16-27. https://doi.org/10.1016/j.agsy.2017.10.005

Anderson, E. (2020). The impact of trade liberalisation on poverty and inequality: Evidence from CGE models. Journal of Policy Modeling, 42(6), 1208-1227. https://doi.org/10.1016/j.jpolmod.2020.05.006

Antoniades, A., Widiarto, I., \& Antonarakis, A. S. (2020). Financial crises and the attainment of the SDGs: An adjusted multidimensional poverty approach. Sustainability Science, 15(6), 1683-1698. https://doi.org/10.1007/s11625-019-00771-z

Ashimov, A., Borovskiy, Y., \& Aidarkhanov, D. (2019). Evaluation of measures to combat poverty based on global multi-country hybrid econometric model. Advances in Systems Science and Applications, 19(3), 118-130. https://doi.org/10.4324/9780429486982-89

Aslam, A. Q., Ahmad, I., Ahmad, S. R., Hussain, Y., Hussain, M. S., Shamshad, J., \& Zaidi, S. J. A. (2018). Integrated climate change risk assessment and evaluation of adaptation perspective in southern Punjab, Pakistan. Science of the Total Environment, 628, 14221436. https://doi.org/10.1016/j.scitotenv.2018.02.129 
Badibanga, T., \& Ulimwengu, J. (2020). Optimal investment for agricultural growth and poverty reduction in the democratic republic of congo a two-sector economic growth model. $\quad$ Applied Economics, 52(2),

$135-155$. https://doi.org/10.1080/00036846.2019.1630709

Bafadal, A., Tinaprilla, N., Arsyad, M., Padangaran, A. M., Jabuddin, L. O., Sani, A., \& Taridala, S. A. A. (2020). Impact of government expenditure on agricultural output and poverty. International Journal of Advanced Science and Technology, 29(6), 1640-1649.

Ballas, D., Clarke, G., Hynes, S., Lennon, J., Morrissey, K., \& O’Donoghue, C. (2013). A review of microsimulation for policy analysis. In Spatial microsimulation for rural policy analysis (pp. 35-54): Springer Science \& Business Media.

Banerjee, O., Cicowiez, M., \& Gachot, S. (2015). A quantitative framework for assessing public investment in tourism-An application to Haiti. Tourism Management, 51, 157-173. https://doi.org/10.1016/j.tourman.2015.05.015

Banson, K. E., Nguyen, N. C., \& Bosch, O. J. (2016). Systemic management to address the challenges facing the performance of agriculture in Africa: case study in Ghana. Systems Research and Behavioral Science, 33(4), 544-574. 10.1002/sres.2372

Beckman, J., Estrades, C., \& Aguiar, A. (2019). Export taxes, food prices and poverty: a global CGE evaluation. Food Security, 11(1), 233-247. https://doi.org/10.1007/s12571-0180876-2

Belem, M., \& Saqalli, M. (2017). Development of an integrated generic model for multi-scale assessment of the impacts of agro-ecosystems on major ecosystem services in West Africa. Journal of Environmental Management, 202, 117-125. https://doi.org/10.1016/j.jenvman.2017.07.018

Benfica, R., Cunguara, B., \& Thurlow, J. (2019). Linking agricultural investments to growth and poverty: An economywide approach applied to Mozambique. Agricultural Systems, 172, 91-100. https://doi.org/10.1016/j.agsy.2018.01.029

Borgomeo, E., Hall, J. W., \& Salehin, M. (2018). Avoiding the water-poverty trap: insights from a conceptual human-water dynamical model for coastal Bangladesh. International Journal of Water Resources Development, 34(6), 900-922. https://doi.org/10.1080/07900627.2017.1331842

Borgomeo, E., Vadheim, B., Woldeyes, F. B., Alamirew, T., Tamru, S., Charles, K. J., et al.Walker, O. (2018). The distributional and multi-sectoral impacts of rainfall shocks: Evidence from computable general equilibrium modelling for the Awash Basin, $\begin{array}{llll}\text { Ethiopia. Ecological } & \text { Economics, }\end{array}$ https://doi.org/10.1016/j.ecolecon.2017.11.038

Bourguignon, F., \& Bussolo, M. (2013). Income distribution in computable general equilibrium modeling. Handbook of computable general equilibrium modeling, 1, 1383-1437. https://doi.org/10.1016/B978-0-444-59568-3.00021-3 
Bowles, D. C., Butler, C. D., \& Friel, S. (2014). Climate change and health in Earth's future. Earth's Future, 2(2), 60-67. https://doi.org/10.1002/2013EF000177

Boysen, O., Jensen, H. G., \& Matthews, A. (2016). Impact of EU agricultural policy on developing countries: A Uganda case study. The Journal of International Trade \& Economic Development, 25(3), $377-402$. https://doi.org/10.1080/09638199.2015.1069884

Boysen, O., \& Matthews, A. (2017). Will Economic Partnership Agreements increase poverty? The case of Uganda. Review of Development Economics, 21(2), 353-382. https://doi.org/10.1111/rode.12272

Breisinger, C., Mukashov, A., Raouf, M., \& Wiebelt, M. (2019). Energy subsidy reform for growth and equity in Egypt: The approach matters. Energy Policy, 129, 661-671. https://doi.org/10.1016/j.enpol.2019.02.059

Brinkmann, K., Kübler, D., Liehr, S., \& Buerkert, A. (2021). Agent-based modelling of the social-ecological nature of poverty traps in southwestern Madagascar. Agricultural Systems, 190, 103125. https://doi.org/10.1016/j.agsy.2021.103125

Bussolo, M., \& Cockburn, J. (2010). Macro-micro analytics: A guide to combining computable general equilibrium and microsimulation modelling frameworks. International Journal of Microsimulation, 3(1).

Bussolo, M., Hoyos, R. E. D., \& Medvedev, D. (2009). Economic growth and income distribution: linking macro-economic models with household survey data at the global level. The International Journal of Microsimulation, 3(1), 92-103. https://doi.org/10.34196/IJM.00027

Byers, E., Gidden, M., Leclère, D., Balkovic, J., Burek, P., Ebi, K., et al.Hillers, A. (2018). Global exposure and vulnerability to multi-sector development and climate change hotspots. Environmental Research Letters, 13(5), 055012. https://doi.org/10.1088/1748-9326/aabf45

Campagnolo, L., \& Davide, M. (2019). Can the Paris deal boost SDGs achievement? An assessment of climate mitigation co-benefits or side-effects on poverty and inequality. World Development, 122, 96-109. https://doi.org/10.1016/j.worlddev.2019.05.015

Cantele, M., Bal, P., Kompas, T., Hadjikakou, M., \& Wintle, B. Equilibrium modeling for environmental science: Exploring the nexus of economic systems and environmental change. In: Wiley Online Library.

Cf, O. (2015). Transforming our world: the 2030 Agenda for Sustainable Development. United Nations: New York, NY, USA.

Cheng, H., Dong, S., Li, F., Yang, Y., Li, Y., \& Li, Z. (2019). A circular economy system for breaking the development dilemma of 'ecological Fragility-Economic poverty' vicious circle: A CEEPS-SD analysis. Journal of Cleaner Production, 212, 381-392. 10.1016/J.JCLEPRO.2018.12.014 
Cheng, X., Shuai, C., Wang, J., Li, W., Shuai, J., \& Liu, Y. (2018). Building a sustainable development model for China's poverty-stricken reservoir regions based on system dynamics. Journal of Cleaner Production, 176, 535-554. https://doi.org/10.1016/j.jclepro.2017.12.068

Cheng, X., Shuai, C. M., Liu, J. L., Wang, J., Liu, Y., Li, W. J., \& Shuai, J. (2018). Modelling environment and poverty factors for sustainable agriculture in the Three Gorges Reservoir Regions of China. Land Degradation \& Development, 29(11), 3940-3953. $10.1002 / 1 d r .3143$

Chitiga - Mabugu, M., Henseler, M., Mabugu, R., \& Maisonnave, H. (2021). Economic and distributional impact of COVID - 19: Evidence from macro - micro modelling of the South African economy. South African Journal of Economics, 89(1), 82-94. https://doi.org/10.1111/saje.12275

Cockburn, J., Maisonnave, H., Robichaud, V., \& Tiberti, L. (2016). Fiscal space and public spending on children in Burkina Faso. International Journal of Microsimulation, 9(1), 5-23. https://doi.org/10.34196/ijm.00126

Cockburn, J., Robichaud, V., \& Tiberti, L. (2018). Energy subsidy reform and poverty in Arab countries: a comparative CGE - microsimulation analysis of Egypt and Jordan. Review of Income and Wealth, 64, S249-S273. https://doi.org/10.1111/roiw.12309

Cororaton, C., Tiongco, M., Inocencio, A., Siriban-Manalang, A. B., \& Lamberte, A. (2018). Climate change, food availability, and poverty: The case of Philippine rice. $D L S U$ Business \& Economics Review, 28(1), 70-83.

Cororaton, C. B., \& Yu, K. D. S. (2019). Assessing the poverty and distributional impact of alternative rice policies in the Philippines. DLSU Business \& Economics Review, 28(2), 169-182.

Cristea, M., Georgiana Noja, G., Dănăcică, D. E., \& Ştefea, P. (2020). Population ageing, labour productivity and economic welfare in the European Union. Economic ResearchEkonomska istraživanja, 33(1),

1354-1376. https://doi.org/10.1080/1331677X.2020.1748507

Cuaresma, J. C., Fengler, W., Kharas, H., Bekhtiar, K., Brottrager, M., \& Hofer, M. (2018). Will the Sustainable Development Goals be fulfilled? Assessing present and future global poverty. Palgrave Communications, 4(1), 29. 10.1057/s41599-018-0083-y

Cury, S., Pedrozo Junior, E., \& Coelho, A. M. (2016). Cash transfer policies, taxation and the fall in inequality in Brazil an integrated microsimulation-CGE analysis. International Journal of Microsimulation, 9(1), 55-85. https://doi.org/10.34196/IJM.00128

Daregot, B., Ayalneh, B., Belay, K., \& Degnet, A. (2015). Poverty and natural resources degradation: analysis of their interactions in lake tana basin, Ethiopia. Journal of International Development, 27(4), 516-527. https://doi.org/10.1002/jid.2914

Darwiche, A. (2009). Modeling and reasoning with Bayesian networks: Cambridge University 
Press.

De Neve, J. E., \& Sachs, J. D. (2020). The SDGs and human well-being: a global analysis of synergies, trade-offs, and regional differences. Scientific Reports, 10(1), 1-12. https://doi.org/10.1038/s41598-020-71916-9

Devarajan, S., Go, D. S., Maliszewska, M., Osorio-Rodarte, I., \& Timmer, H. (2015). Stresstesting Africa's recent growth and poverty performance. Journal of Policy Modeling, 37(4), 521-547. https://doi.org/10.1016/j.jpolmod.2015.04.006

DIZON, R. L. (2021). Tax incidence of Philippine tax reform: Poverty and distributional effect. The Journal of Asian Finance, Economics, and Business, 8(2), 281-288. https://doi.org/10.13106/jafeb.2021.vo18.no2.0281

Duque, J. C., Patino, J. E., Ruiz, L. A., \& Pardo-Pascual, J. E. (2015). Measuring intra-urban poverty using land cover and texture metrics derived from remote sensing data. Landscape and Urban Planning, 135, 11-21. https://doi.org/10.1016/j.landurbplan.2014.11.009

El Wali, M., Golroudbary, S. R., \& Kraslawski, A. (2021). Circular economy for phosphorus supply chain and its impact on social Sustainable Development Goals. Science of The Total Environment, 777, 146060. https://doi.org/10.1016/j.scitotenv.2021.146060

FAO. (2017). Ending poverty and hunger by investing in agriculture and rural areas. Retrieved from http://www.fao.org/3/a-i7556e.pdf

Feltenstein, A., Mejia, C., Newhouse, D., \& Sedrakyan, G. (2017). The poverty implications of alternative tax reforms: Results from a numerical application to Pakistan. Journal of Asian Economics, 52, 12-31. https://doi.org/10.1016/j.asieco.2017.06.004

Foster, J., Greer, J., \& Thorbecke, E. (2010). The Foster-Greer-Thorbecke (FGT) poverty measures: 25 years later. The Journal of Economic Inequality, 8(4), 491-524. https://doi.org/10.1007/s10888-010-9136-1

Fuchs, M., Hollan, K., \& Gasior, K. (2017). Simulation of an application of the Hartz-IV reform in Austria. Public Sector Economics, 41(4), 479-500. https://doi.org/10.3326/pse.41.4.4

Fujimori, S., Hasegawa, T., \& Oshiro, K. (2020). An assessment of the potential of using carbon tax revenue to tackle poverty. Environmental Research Letters, 15(11), 114063. https://doi.org/10.1088/1748-9326/abb55d

Garchitorena, A., Sokolow, S., Roche, B., Ngonghala, C., Jocque, M., Lund, A., et al.Jones, J. (2017). Disease ecology, health and the environment: a framework to account for ecological and socio-economic drivers in the control of neglected tropical diseases. Philosophical Transactions of the Royal Society B: Biological Sciences, 372(1722), 20160128. https://doi.org/10.1098/rstb.2016.0128

Gilliland, T. E., Sanchirico, J. N., \& Taylor, J. E. (2019). An integrated bioeconomic local economy-wide assessment of the environmental impacts of poverty programs. 
Proceedings of the National Academy of Sciences, 116(14), 6737-6742. https://doi.org/10.1073/pnas.1816093116

Glomsrød, S., Wei, T., Aamaas, B., Lund, M. T., \& Samset, B. H. (2016). A warmer policy for a colder climate: Can China both reduce poverty and cap carbon emissions? Science of the Total Environment, 568, 236-244. https://doi.org/10.1016/j.scitotenv.2016.06.005

Grace, D., Lindahl, J., Wanyoike, F., Bett, B., Randolph, T., \& Rich, K. M. (2017). Poor livestock keepers: ecosystem-poverty-health interactions. Philosophical Transactions of the Royal Society B: Biological Sciences, 372(1725), 20160166. http://dx.doi.org/10.1098/rstb.2016.0166

Griggs, D., Nilsson, M., Stevance, A., \& McCollum, D. (2017). A guide to SDG interactions: From science to implementation: International Council for Science, Paris.

Hallegatte, S., \& Rozenberg, J. (2017). Climate change through a poverty lens. Nature Climate Change, 7(4), 250-256. https://doi.org/10.1038/nclimate3253

Hans, L., \& Carolina, D. B. (2009). Analyzing policies for achieving the MDGs with MAMS. Retrieved from https://isap.iges.or.jp/2009/jp/pdf/day1/26s105_Lofgren.pdf

Hertel, T., Verma, M., Ivanic, M., Magalhaes, E., Ludena, C., \& Rios, A. R. (2011). GTAPPOV: A framework for assessing the national poverty impacts of global economic and environmental policies. https://doi.org/10.22004/ag.econ.283430

Hufkens, T., Figari, F., Vandelannoote, D., \& Verbist, G. (2020). Investing in subsidized childcare to reduce poverty. Journal of European Social Policy, 30(3), 306-319. https://doi.org/10.1177/0958928719868448

Hughes, B. B. (2018). International Futures: Choices in the face of uncertainty: Routledge.

Hughes, B. B. (2019). International Futures: Building and using global models: Academic Press.

Hughes, B. B., Irfan, M. T., Khan, H., Kumar, K. B., Rothman, D. S., \& Solórzano, J. R. (2015). Reducing global poverty: Routledge.

Hughes, B. B., \& Narayan, K. (2021). Enhancing integrated analysis of national and global goal pursuit by endogenizing economic productivity. PloS One, 16(2), e0246797. https://doi.org/10.1371/journal.pone.0246797

Inagaki, S. (2018). Dynamic microsimulation model of impoverishment among elderly women in Japan. Frontiers in Physics, 6, 22. https://doi.org/10.3389/fphy.2018.00022

Intriligator, M. D. (1983). Economic and econometric models. Handbook of Econometrics, 1, 181-221. https://doi.org/10.1016/S1573-4412(83)01007-7

Islam, M. S., \& Haider, M. Z. (2018). Poverty and technical efficiency in presence of heterogeneity in household behaviours: Evidence from Bangladesh. International Journal of Social Economics. https://doi.org/10.1108/IJSE-04-2017-0171

Jeong-Soo, O. H., \& Kyophilavon, P. (2015). Impact of the Asean-Korea free trade agreement 
(AKFTA) on poverty: the role of technology transfer. International Journal of Economic Research, 12(3).

Jin, G., Deng, X., Chu, X., Li, Z., \& Wang, Y. (2017). Optimization of land-use management for ecosystem service improvement: A review. Physics and Chemistry of the Earth, Parts A/B/C, 101, 70-77. https://doi.org/10.1016/j.pce.2017.03.003

Kabajulizi, J., Keogh-Brown, M. R., \& Smith, R. D. (2017). The welfare implications of public healthcare financing: a macro-micro simulation analysis of Uganda. Health Policy and Planning, 32(10), 1437-1448. https://doi.org/10.1093/heapol/czx125

Karmozdi, K. M., Kohansal, M. R., \& Ghorbani, M. (2020). Sustainable economic rural development system pattern in Ghaemshahr: an application of the developed TOPMARD core model. Environment, Development and Sustainability, 22(6), 5793-5817. https://doi.org/10.1007/s10668-019-00451-z

Kosow, H., \& Gaßner, R. (2008). Methods of future and scenario analysis: Overview, assessment, and selection criteria (Vol. 39): DEU.

Kroll, C., Warchold, A., \& Pradhan, P. (2019). Sustainable Development Goals (SDGs): Are we successful in turning trade-offs into synergies? Palgrave Communications, 5(1), 1-11. https://doi.org/10.1057/s41599-019-0335-5

Kruseman, G., Bairagi, S., Komarek, A. M., Molero Milan, A., Nedumaran, S., Petsakos, A., et al.Yigezu, Y. A. (2020). CGIAR modeling approaches for resource - constrained scenarios: II. Models for analyzing socioeconomic factors to improve policy recommendations. Crop Science, 60(2), 568-581. https://doi.org/10.1002/csc2.20114

Kyophilavong, P., Bin, X., Vanhnala, B., Wongpit, P., Phonvisay, A., \& Onphanhdala, P. (2017). The impact of Chinese FDI on economy and poverty of Lao PDR. International Journal of China Studies, 8(2), 259-276.

Kyophilavong, P., Wong, M. C., Souksavath, S., \& Xiong, B. (2017). Impacts of trade liberalization with China and Chinese FDI on Laos: Evidence from the CGE model. Journal of Chinese Economic and Business Studies, 15(3), 215-228. https://doi.org/10.1080/14765284.2017.1346923

Laborde, D., Martin, W., \& Vos, R. (2021). Impacts of COVID - 19 on global poverty, food security, and diets: Insights from global model scenario analysis. Agricultural Economics. https://doi.org/10.1111/agec.12624

Lázár, A. N., Nicholls, R. J., Hall, J. W., Barbour, E. J., \& Haque, A. (2020). Contrasting development trajectories for coastal Bangladesh to the end of century. Regional Environmental Change, 20(3), 1-14. https://doi.org/10.1007/s10113-020-01681-y

Liyanaarachchi, T. S., Naranpanawa, A., \& Bandara, J. S. (2016). Impact of trade liberalisation on labour market and poverty in Sri Lanka. An integrated macro-micro modelling approach. Economic Modelling, $\quad 59, \quad$ 102-115. https://doi.org/10.1016/j.econmod.2016.07.008 
Llambi, C., Laens, S., \& Perera, M. (2016). Assessing the impacts of a major tax reform: a CGE-microsimulation analysis for Uruguay. International Journal of Microsimulation, 9(1), 134-166. https://doi.org/10.34196/IJM.00131

Lofgren, H., Cicowiez, M., \& Diaz-Bonilla, C. (2013). MAMS - A computable general equilibrium model for developing country strategy analysis. Handbook of Computable General Equilibrium Modeling, 1, 159-276. 10.1016/B978-0-444-59568-3.00004-3

Mahadevan, R., Nugroho, A., \& Amir, H. (2017). Do inward looking trade policies affect poverty and income inequality? Evidence from Indonesia's recent wave of rising protectionism. Economic Modelling, 23-34. https://doi.org/10.1016/j.econmod.2016.12.031

Malerba, D., \& Wiebe, K. S. (2021). Analysing the effect of climate policies on poverty through employment channels. Environmental Research Letters, 16(3), 035013. https://doi.org/10.1088/1748-9326/abd3d3

Marcinko, C. L., Nicholls, R. J., Daw, T. M., Hazra, S., Hutton, C. W., Hill, C. T., et al.Das, I. (2021). The development of a framework for the integrated assessment of SDG tradeoffs in the sundarban biosphere reserve. Water, 13(4), 528. https://doi.org/10.3390/w13040528

Mardones, C. (2015). An income tax increase to fund higher education: A CGE analysis for Chile. Economic Systems Research, 27(3), 324-344. https://doi.org/10.1080/09535314.2015.1030359

Medeiros, V., Ribeiro, R. S. M., \& do Amaral, P. V. M. (2021). Infrastructure and household poverty in Brazil: A regional approach using multilevel models. World Development, 137, 105118. https://doi.org/10.1016/j.worlddev.2020.105118

MI. (2021). Integrated Sustainable Development Goals (iSDG) Model. Retrieved from https://www.millennium-institute.org/isdg

Milante, G., Hughes, B., \& Burt, A. (2016). Poverty eradication in fragile places: Prospects for harvesting the highest hanging fruit by 2030. Stability: International Journal of Security and Development, 5(1). http://doi.org/10.5334/sta.435

Mio, C., Panfilo, S., \& Blundo, B. (2020). Sustainable Development Goals and the strategic role of business: A systematic literature review. Business Strategy and the Environment, 29(8), 3220-3245. https://doi.org/10.1002/bse.2568

Moallemi, E. A., Kwakkel, J., de Haan, F. J., \& Bryan, B. A. (2020). Exploratory modeling for analyzing coupled human-natural systems under uncertainty. Global Environmental Change, 65, 102186. 10.1016/j.gloenvcha.2020.102186

Mohammed, T. (2018). Simulation of the impact of economic policies on poverty and inequality: GEM in micro-simulation for the Algerian economy. International Review of Applied Economics, 32(3), 308-330. https://doi.org/10.1080/02692171.2017.1342778

Moher, D., Liberati, A., Tetzlaff, J., Altman, D. G., \& Group, P. (2009). Preferred reporting 
items for systematic reviews and meta-analyses: the PRISMA statement. PLoS medicine, 6(7), e1000097. https://doi.org/10.1371/journal.pmed.1000097

Montaud, J. M., Pecastaing, N., \& Tankari, M. (2017). Potential socio-economic implications of future climate change and variability for Nigerien agriculture: A countrywide dynamic CGE-Microsimulation analysis. Economic Modelling, 63, 128-142. https://doi.org/10.1016/j.econmod.2017.02.005

Mukarati, J., Mongale, I., \& Makombe, G. (2020). Land redistribution and the South African economy. Agricultural Economics, 66(1), 46-54. https://doi.org/10.17221/120/2019$\underline{\text { AGRICECON }}$

Ndhleve, S., Obi, A., \& Nakin, M. (2017). Public spending on agriculture and poverty in Eastern cape province, South Africa. African Studies Quarterly, 17(2), 23-46.

Nguyen, H. M., \& Nguyen, T. A. (2019). Investigating the determinants of household welfare in the Central Highland, Vietnam. Cogent Economics \& Finance, 7(1), 1684179. https://doi.org/10.1080/23322039.2019.1684179

Nöldeke, B., Winter, E., Laumonier, Y., \& Simamora, T. (2021). Simulating agroforestry adoption in rural Indonesia: The potential of trees on farms for livelihoods and environment. Land, 10(4), 385. https://doi.org/10.3390/land10040385

Oladokun, M. G. (2014). Dynamic modelling of the socio-technical systems of household energy consumption and carbon emissions. Heriot-Watt University,

Pradhan, P., Costa, L., Rybski, D., Lucht, W., \& Kropp, J. P. (2017). A systematic study of sustainable development goal (SDG) interactions. Earth's Future, 5(11), 1169-1179. https://doi.org/10.1002/2017EF000632

Renner, S. (2018). Poverty and distributional effects of a carbon tax in Mexico. Energy Policy, 112, 98-110. https://doi.org/10.1016/j.enpol.2017.10.011

Rey, S. J. (2000). Integrated regional econometric+ input-output modeling: Issues and opportunities. Papers in Regional Science, 79(3), 271-292. https://doi.org/10.1007/PL00013613

Robinson, S., Mason-D'Croz, D., Sulser, T., Islam, S., Robertson, R., Zhu, T., et al.Rosegrant, M. W. (2015). The international model for policy analysis of agricultural commodities and trade (IMPACT): Model description for version 3. Washington: The International Food Policy Research Institute.

Rosegrant, M. W., Sulser, T. B., Mason-D’Croz, D., Cenacchi, N., Nin-Pratt, A., Dunston, S., et al.Robinson, S. (2017). Quantitative foresight modeling to inform the CGIAR research portfolio: The International Food Policy Research Institute.

Rosenzweig, C., Ruane, A. C., Antle, J., Elliott, J., Ashfaq, M., Chatta, A. A., et al.Havlik, P. (2018). Coordinating AgMIP data and models across global and regional scales for 1.5 $\mathrm{C}$ and $2.0 \mathrm{C}$ assessments. Philosophical Transactions of the Royal Society A: Mathematical, Physical and Engineering Sciences, 376(2119), 20160455. 
Salotti, S., \& Trecroci, C. (2018). Cross-country evidence on the distributional impact of fiscal policy.

Applied

Economics,

$50(51)$,

5521-5542. https://doi.org/10.1080/00036846.2018.1487001

Schleicher, J., Schaafsma, M., \& Vira, B. (2018). Will the Sustainable Development Goals address the links between poverty and the natural environment? Current Opinion in Environmental Sustainability, 34, 43-47. https://doi.org/10.1016/j.cosust.2018.09.004

Shrime, M. G., Sekidde, S., Linden, A., Cohen, J. L., Weinstein, M. C., \& Salomon, J. A. (2016).

1051

1052 Sustainable development in surgery: the health, poverty, and equity impacts of charitable surgery in Uganda. PLoS One, 11(12), e0168867. https://doi.org/10.1371/journal.pone.0168867

Shuaibu, M. (2017). The effect of trade liberalisation on poverty in Nigeria: A micro-macro framework. International Economic Journal, 31(1), 68-93. https://doi.org/10.1080/10168737.2016.1221984

Siriban-manalang, A. B., Cororaton, C. B., Inocencio, A. B., \& Tiongco, M. (2016). Assessing the potential economic and poverty effects of the national greening program1. DLSU Business \& Economics Review, 26(1), 1-1.

1060 Solaymani, S. (2017). Agriculture and poverty responses to high agricultural commodity prices. Agricultural Research, 6(2), 195-206. https://doi.org/10.1007/s40003-017-0253-y

Solaymani, S., \& Yusoff, N. Y. B. M. (2018). Poverty effects of food price escalation and mitigation options: The case of Malaysia. Journal of Asian and African Studies, 53(5), 685-702. https://doi.org/10.1177/0021909617714275

Sterman, J. (2000). Business dynamics: McGraw-Hill, Inc.

Suich, H., Howe, C., \& Mace, G. (2015). Ecosystem services and poverty alleviation: A review of the empirical links. Ecosystem Services, 12, 137-147. 10.1016/J.ECOSER.2015.02.005

Supriyadi, E., \& Kausar, D. R. K. (2017). The economic impact of international tourism to overcome the unemployment and the poverty in Indonesia. Journal of Environmental Management \& Tourism, 8(2 (18)), 451. https://doi.org/10.14505//jemt.v8.2(18).18

Sutherland, H., \& Figari, F. (2013). EUROMOD: The European Union tax-benefit microsimulation model. International Journal of Microsimulation, 6(1), 4-26. 10.34196/IJM.00075

Swart, R. J., Raskin, P., \& Robinson, J. (2004). The problem of the future: sustainability science and scenario analysis. Global Environmental Change, 14(2), 137-146. https://doi.org/10.1016/j.gloenvcha.2003.10.002 change: The Pacific atoll nation of Tuvalu. Environmental Economics and Policy Studies, 20(4), 705-739. https://doi.org/10.1007/s10018-018-0212-2 
1081

1082

1083

1084

1085

1086

1087

1088

1089

1090

1091

1092

1093

1094

1095

1096

1097

1098

1099

1100

1101

1102

1103

1104

1105

1106

1107

1108

1109

1110

1111

1112

1113

1114

1115

1116

1117

Ten Raa, T. (2009). Input-output economics: Theory and applications-featuring Asian economies. London: World Scientific.

Tiberti, L., Cicowiez, M., \& Cockburn, J. (2017). A top-down behaviour (TDB) microsimulation toolkit for distributive analysis. Partnership for Economic Policy Working Paper(2017-24). http://dx.doi.org/10.2139/ssrn.3159366

United Nations. (2019). Sustainable Development Goals 1. Retrieved from https://sustainabledevelopment.un.org/sdg1

United Nations. (2020). Goal 1: End poverty in all its forms everywhere. Retrieved from https://www.un.org/sustainabledevelopment/poverty/

United Nations. (2021). The SDGs in action. Retrieved from https://www.undp.org/sustainabledevelopment-goals

van Wesenbeeck, C., Keyzer, M., van Veen, W., \& Qiu, H. (2021). Can China's overuse of fertilizer be reduced without threatening food security and farm incomes? Agricultural Systems, 190, 103093. https://doi.org/10.1016/j.agsy.2021.103093

Vyas-Doorgapersad, S. (2018). Designing measurement instruments for Sustainable Development Goals one, five and nine. African Journal of Public Affairs, 10(3), 118133.

Wang, B. W., Wang, Y. N., Li, H., \& Yao, S. B. (2019). Regional characteristics and causes of farmers' poverty in the perspective of agricultural development. Agronomia, 36(1), 3345.

Wang, W., Ren, Q., \& Yu, J. (2018). Impact of the ecological resettlement program on participating decision and poverty reduction in southern Shaanxi, China. Forest Policy and Economics, 95, 1-9. https://doi.org/10.1016/j.forpol.2018.06.007

Wang, X., Chen, K. Z., Robinson, S., \& Huang, Z. (2017). Will China's demographic transition exacerbate its income inequality?-CGE modeling with top-down microsimulation. Journal of the Asia Pacific Economy, 22(2), 227-252. https://doi.org/10.1080/13547860.2016.1263043

World Bank. (2007). World development report 2008: Agriculture for development (0821368079). World Bank.

Yusuf, A. A. (2018). The direct and indirect effect of cash transfers: the case of Indonesia. International Journal of Social Economics.

Zhou, Y., Li, Y., \& Liu, Y. (2020). The nexus between regional eco-environmental degradation and rural impoverishment in China. Habitat International, 96, 102086. https://doi.org/10.1016/j.habitatint.2019.102086

Zidouemba, P. R., \& Gerard, F. (2018). Does agricultural productivity actually matter for food security in a landlocked sub - Saharan African country? The case of Burkina Faso. Canadian Journal of Agricultural Economics, 66(1), 103-142. 10.1111/cjag.12140 
1118 Zorrilla-Miras, P., Mahamane, M., Metzger, M. J., Baumert, S., Vollmer, F., Luz, A. C., et 1119 al.Nhantumbo, I. (2018). Environmental conservation and social benefits of charcoal production in Mozambique. Ecological Economics, 144, 100-111. https://doi.org/10.1016/j.ecolecon.2017.07.028

1122 